\title{
Socialinès organizacijos raida Dubingių mikroregione I a. - XVI a. viduryje: teorinis modelis
}

\author{
RIMVYDAS LAUŽIKAS \\ Vilniaus universitetas, Universiteto g. 3, LT-01513 Vilnius \\ El. paštas: rimvydas.lauzikas@kf.vu.lt
}

\begin{abstract}
Straipsnyje (1) pateikiami socialinès organizacijos tyrimo rezultatai, remiantis I. Prigogineo sistemų teorija ir socialinio kapitalo teorijomis, pagrindžiamas bendrasis visuomenès socialinès organizacijos proceso teorinis modelis ir konkretaus Dubingių mikroregiono bendruomenès socialinès raidos modelis nuo vietinès geležies rūdos gavybos pradžios (senasis geležies amžius) iki Valakų reformos XVI a. viduryje.
\end{abstract}

Raktažodžiai: Dubingių mikroregionas, Lietuvos Didžioji Kunigaikštystė, socialinė organizacija, socialinis kapitalas, socialinès interakcijos, visuomenès raida, proceso modelis

\section{IVADAS}

Visuomenès ir valstybès raidos tyrimai, ịvairių raidos schemų, modelių kūrimas yra viena gausiausių ne tik istorijos ar archeologijos, bet ir sociologijos, filosofijos, net teologijos tyrimų krypčių. Europinès kultūros erdveje bene pirmasis tarp jų - biblinis pranašas Danielius, VII-VI a. pr. Kr. gyvenusiam Babilonijos karaliui Nabuchodonosarui II išaiškinęs sapną: esą krašto istoriją sudarys penki periodai - aukso, sidabro, bronzos, geležies ir molio karalystės (Dan 2). Nuo to laiko buvo sukurta įvairiausių istorinès raidos modelių, tarp kurių vyrauja teologijos ir istorijos filosofijos globalūs modeliai (Joakimo Floriečio, šv. Augustino, Karlo Markso, Osvaldo Špenglerio ir pan.). Idejjiniu lygmeniu su šiais globaliais modeliais yra susietos, bet empiriniais duomenimis grịstos istorijos periodizacijos (pavyzdžiui, Christiano Jurgenseno Thomseno „trijų amžių“ sistema) ir lokalių visuomenių tyrimai, besiskiriantys teritorine, chronologine apréptimi ir / ar metodologinėmis prieigomis (Lewio Henry Morgano atlikti irokėzų tyrimai, Vere Gordono Childe’o neolito revoliucijos ar Marijos Gimbutienès senosios Europos raidos

(1) Straipsnis parengtas vykdant projektą „Lietuvos valstybės ištakos Dubingių mikroregiono tyrimų duomenimis“" (projekto Nr. VP1-3.1-ŠMM-07-K-01-037), finansuojamą iš Europos Sajungos fondų lěšų pagal 2007-2013 m. Žmogiškujjų išteklių plettros veiksmų programos 3-iojo prioriteto „Tyrejjų gebėjimų stiprinimas“ VP1.3.1-ŠMM-07-K priemonę „Parama mokslininkų ir kitų tyrëjų mokslinei veiklai (visuotinè dotacija)“. Už idejas, patarimus, pastabas ir diskusijas, kurios buvo svarbios atliekant š̨ tyrimą, dèkoju projekto kolegoms prof. Albinui Kuncevičiui, prof. Rimantui Jankauskui, Renaldui Augustinavičiui, Ramūnui Šmigelskui, taip pat dr. Vykintui Vaitkevičiui, dr. Daivai Vaitkevičienei ir 4-ojo prigimtinès kultūros seminaro „Žemė juodoji: veldèmé, valda ir paveldètosios vertybès“ dalyviams. 
idejjos). Per tą laiką išsikristalizavo įvairios visuomenès tyrimų metodologinès prieigos, besiskiriančios empirinio objekto traktavimu (individas, socialinė klasé, visuomenè apskritai ir pan.). Dideliu postūmiu čia buvo Charleso Roberto Darwino gamtos tyrimai, paskatinę empirinio tyrimo objektu laikyti populiaciją (rūšì), ir vèliau, jau XX a., išplètota sistemų teorija, pagal kurią visuomenė interpretuota ne kaip individų matematinė suma, o kaip sistema, kurioje dèl individų tarpusavio sąveikos atsiranda kokybiškai naujų reiškinių, nebūdingų paskiriems individams [59, 56-64].

Visuomenès raida Lietuvoje analizuota įvairių autorių darbuose, kuriuos galètume skirti ì dvi dalis pagal autorių priklausomybę skirtingiems mokslams. Priešistorinio laikotarpio (paprastai iki valstybès susidarymo XIII a.) visuomenè nagrinejjama archeologų darbuose, pradedant XIX a. romantizmo paveiktomis Eustachijaus Tiškevičiaus ir Adomo Honorio Kirkoro idejomis [32, 16] bei moksliniais Lietuvos archeologijos bruožais [26]. Ikivalstybinio laikotarpio visuomenès raidai skirtos dalys sintetinèse monografijose apie skirtingus priešistorès laikotarpius: akmens, bronzos, senąji geležies ir vidurini geležies amžius [53; 14; 39; 63]. Laidojimo paminklų tyrimų pritaikymo visuomenès rekonstrukcijai metodologiją pagrindè ir vakarų baltų visuomenes nagrinèjo Eugenijus Jovaiša [21;22], biosocialinius klausimus - Rimantas Jankauskas [18]. Naujumu, apimtimi ir metodologija iš priešistorès visuomenių tyrimų išsiskiria Lauryno Vyčio Kurilos 2009 m. apginta humanitarinių mokslų daktaro disertacija „Socialinè organizacija Rytų Lietuvoje III-XII a. (laidojimo paminklų duomenimis)“ bei šios disertacijos pagrindu parengti moksliniai straipsniai $[30 ; 31 ; 32 ; 33]$. L. Kurilos tyrimų turinys artimiausias šiame straipsnyje pristatomam tyrimui, nes Dubingių mikroregionas yra Rytų Lietuvos dalis. Aptardamas temos ištyrimo lygi L. Kurila pažymi, kad: „...Lietuvos archeologų darbus... <..> ...mažai veikẻ Vakaruose verdančios diskusijos socialinès organizacijos ir laidojimo paminklų, kaip jos indikatorių, klausimais...< ..> ... šios srities tyrinėjimai Lietuvoje yra labai mažai išplètoti teoriniu lygmeniu... <...> ...tai lemia gana nekritišką požiūrị i tiesioginị laidosenos ir socialinio statuso ryšị bei palyginti siaurą nagrinèjamų temų ratą..." [32, 34-35]. Nors šiais laikais visuotinai sutariama, kad istorijos ir archeologijos mokslų objektą skiria ne tiek chronologinė, kiek metodologinè riba [3, 5-9], Lietuvos visuomenès tyrimuose archeologai ir istorikai „korektiškai“ neperžengia XIII a. sandūros į vieną ar kitą pusę ir menkai naudoja istorinius ir archeologinius empirinius duomenis kartu bei tyrimo metodologijas tarpdalykiniuose tyrimuose priimtais būdais. Mindaugo karalystės ir vèlesnès LDK visuomenès socialinè raida priskiriama istorikų prerogatyvai, o ankstyvesnius laikus tiria archeologai.

Jau pačiuose ankstyviausiuose istorikų Alberto Vijūko-Kojelavičiaus ar Motiejaus Strijkovskio veikaluose rasime socialinès raidos aspektų. Šio klausimo įvairiausiuose kontekstuose ir su ịvairiomis interpretacijomis neaplenkè dauguma XVIII-XIX a. istorikų, rašiusių LDK istorijos tema (Nikolajus Karamzinas, Teodoras Narbutas, Matvejus Liubavskis, Simonas Daukantas, Joachimas Lelevelis ir kt.) (2). Tarpukariu kokybiškai nauju metodologiniu požiūriu išsiskiria Vilniaus Stepono Batoro universiteto profesoriaus Henriko Lowmianskio dviejų tomų habilitacinis darbas Studia nad poczatkami społeczeństwa i państwa litewskiego (1932), o nepriklausomoje Lietuvoje medžiagos sintetiškumo ir naratyvų požiūriais - Adolfo Šapokos redaguota Lietuvos istorija (1936) bei vèliau išeivijoje pasirodžiusi Zenono

(2) Kadangi XIX a. Lietuvos istoriografija yra apžvelgta Egidijaus Aleksandravičiaus ir Antano Kulakausko [1], tarpukario Lietuvos istoriografija - Povilo Lasinsko [34], o sovietinio laikotarpio istoriografija - Alfredo Bumblausko ir Nerijaus Šepečio [5] publikacijose, tolesnejje istoriografinèje apžvalgoje išskirsime tik svarbiausius autorius ir jų darbus. 
Ivinskio Lietuvos istorija iki Vytauto Didžiojo mirties. Sovietiniu laikotarpiu dèl oficialiosios marksistinès istorijos filosofijos visuomenès raida paprastai buvo nagrinejjama ekonominiuose marksistinès-lenininès istorijos raidos schemos (nuo pirmykštės bendruomenès iki komunizmo) kontekstuose. Taip ji pateikiama ir to meto sintetiniuose Lietuvos istorijos veikaluose $[23 ; 65 ; 79]$. Nepriklausomos Lietuvos metais socialinè istorija tyrinejjama įvairiais aspektais, tačiau sistemiškumo požiūriu ịdomiausi sintetiniai istorijos veikalai $[11 ; 15 ; 13 ; 24$; 25], kuriuose pateikiamas naujas, su europiniais socialinès raidos tyrimų kontekstais susietas požiūris ị LDK visuomenès raidą. Nuosekli visuomenès raida I-XVI a. Lietuvoje iki šiol nèra pakankamai sistemiškai analizuota.

Straipsnyje pateikiamo socialinès organizacijos tyrimo teoriniu pagrindu buvo pasirinkta Ilyos Prigogine’o sistemų teorija [48], pagal kurią visuomenè yra traktuojama kaip sistema ir nagrinejjama populiacijos, o ne individų ar pavienių socialinių sluoksnių lygmeniu. Dèl tokio teorinio pasirinkimo tyrimas yra orientuotas ị socialinių struktūrų ir socialinès organizacijos raidą. Toks požiūris sudarẻ sąlygas tyrimo sistemiškumui ir galimybei pritaikyti socialinio kapitalo konceptą ir leidžia demografinę, ekonominę ir visuomenès raidą susieti naujais aspektais. Tyrimo objektas yra konkrečiame Dubingių mikroregione gyvenusios bendruomenès. Pristatomo tyrimo tikslai - teoriškai pagrịsti bendrąji ir konkretaus mikroregiono bendruomenių socialinès organizacijos raidos (proceso) modelius bei suformuluoti hipotezes tolesniems empiriniams Dubingių mikroregiono bendruomenių tyrimams. Tyrimo ankstyvoji chronologinè riba susieta su senojo geležies amžiaus pradžia Lietuvoje (vèlyvoji brūkšniuotosios keramikos kultūros fazè). Archeologijos moksle issigalejusi nuomonè, kad šiuo laikotarpiu (tik nuo I a. pirmosios pusès) buvo pradèta vietinè geležies gamyba (metalurgija) ir metaliniai įrankiai išstūmẻ kaulinius ir akmeninius. Tokia naujovė nulèmė ir socialinès organizacijos pokyčius. Tyrimo vėlyvoji chronologinè riba siejama su XVI a. viduryje vykdyta Valakų reforma, kuri galutinai įtvirtino trilaukę sejomainą ir baudžiaviniais santykiais grịstą socialinę organizaciją. Tyrime buvo laikomasi dedukcinio metodologinio požiūrio, kuris buvo pakankamai efektyvus projekte „Lietuvos valstybės ištakos Dubingių mikroregiono tyrimų duomenimis“ tiriant mikroregiono teritorinių struktūrų (teritorializacijos) raidą [27, 11-39; 29]. Tyrime taikyti šaltinių kritinès lyginamosios analizès ir modeliavimo metodai. Dalis straipsnio teiginių dèl empirinių duomenų trūkumo turètų būti traktuojami kaip mokslinès problemos apibrèžimas ar hipotezès.

Svarbiausi straipsnyje vartojami terminai yra visuomenè, bendruomenè, socialinè struktūra ir socialinè organizacija. Mokslinès literatūros analizė išryškina šių terminų daugiaprasmiškumą ir nepakankamą apibrèžtumą, todèl atliekant tyrimą buvo laikytasi enciklopedinio pobūdžio apibrèžčių. Visuomenès ir bendruomenės sąvokos yra vartojamos matematinei statistikai būdingu populiacijos ir imties aspektu, kai visuomenè yra „...aibė objektų, turinčių tyrèją dominančių savybių...“, o imtis - „...tyrejjo stebima populiacijos dalis..." [72], visuomenę apibrèžiant kaip tam tikru laiku ir tam tikroje teritorijoje gyvenančių žmonių visumą: „...istorinę žmonių santalką, kuriai daro įtaką vieta ir laikas.... [71]. Straipsnyje pristatomame tyrime visuomenè yra traktuojama kaip žmonių visuma, gyvenanti I-XVI a. pirmosios pusès Lietuvoje - LDK teritorijoje, kurioje I-XIV a. vyravo pagonybė, o nuo XIV a. pabaigos pradejo plisti katalikybè. Tyrime neanalizuojami socialinès raidos savitumai ortodoksų gyvenamoje LDK teritorijoje; čia dèl kitokių tarpkultūrinių ryšių, ankstyvo valstybingumo bei krikšto socialinės raidos procesai ženkliai skyrèsi. Bendruomenè - aptartos visuomenės dalis, gyvenusi Dubingių mikroregione. 
Šiuo atveju mikroregionas komunikaciniu požiūriu suprantamas kaip natūraliai, istoriškai susiklosčiusi kultūrinè ir gamtinė erdvė, kurios gyventojai palaiko glaudžius ryšius, artimai bendrauja. Dubingių mikroregiono teritorija yra artima Dubingių parapijos teritorijai XVI-XIX a. pradžioje (3). Socialinè organizacija straipsnyje vartojama sociologine prasme - kaip visuomenès narių (individų) ir jų grupių tarpusavio ryšių sistema, susieta abipusių issipareigojimų, funkcijų ir veiklų pasidalijimu [61]. O socialinė struktūra gali būti apibrèžiama kaip socialinès organizacijos, sistemos dalis (posistemè), pamatinis, ilgalaikis ir socialinę organizaciją veikiantis visuomenès elementas $[6,452]$.

\section{SOCIALINĖS ORGANIZACIJOS MODELIAI}

Straipsnyje visuomenès raida nagrinejjama remiantis bendruoju visuomenès ir mikroregiono bendruomenès socialinès raidos proceso modeliais, kurie pagrindžiami I. Prigogine’o sisteminiu požiūriu, pagal kurị socialinès organizacijos yra atvirosios, evoliucionuojančios, disipatyviosios sistemos [48, 28-36]. Atviroji sistema reiškia tai, kad kiekviena konkreti visuomenè ar bendruomenè yra atvira sąveikoms su kitomis visuomenèmis ir bendruomenėmis bei tų sąveikų sukeltiems pokyčiams. Straipsnyje pristatomo tyrimo kontekste dviejų visuomenių sąveiką pirmiausia turime interpretuoti kaip komunikacinę sąveiką, tai yra kaip idejų, informacijos, patirties mainus [52, 308]. Kartu šios visuomenès ir bendruomenès yra evoliucionuojančios. Tačiau, skirtingai nuo Ch. Darwino idejjomis grịstos tolygios evoliucijos, I. Prigogine’o sistemų teorijos požiūriu kiekviena sistema išgyvena tolygios plètros (evoliucijos) ir staigaus sukrètimo (mutacijos) laikotarpius. Kiekvieno laikotarpio metu sistema kinta skirtingu greičiu, tačiau tik tolygūs evoliuciniai pokyčiai yra prognozuojami. Sistemos disipatyvumas rodo, kad mutacijų sukelti pokyčiai vyksta pagal objektyvią laiko strèlę ir permainos bei procesai yra negrịžtami. Šiuo požiūriu pagrịstas bendrasis visuomenès socialinès organizacijos proceso teorinis modelis yra pateikiamas 1 paveiksle.

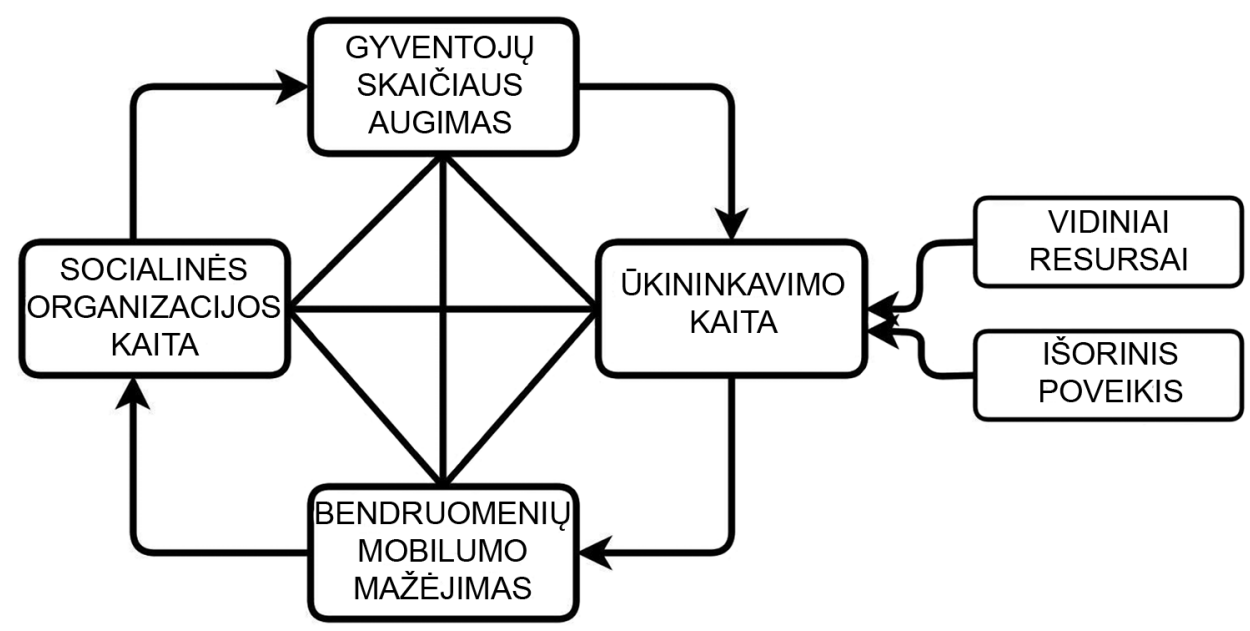

1 pav. Bendrasis socialinès organizacijos proceso modelis

(3) Išsamiau mikroregiono apibrèžimas analizuojamas projekto „Lietuvos valstybès ištakos Dubingių mikroregiono tyrimų duomenimis" vykdytojų publikacijose [27, 12-13; 28, 15-16]. 
Remiantis požiūriu, kad populiacijos dydis yra vienas svarbiausių sistemos parametrų $[52,421]$, modeliuojamo proceso atskaitos tašku pasirinktas gyventojų skaičius (populiacijos dydis), o socialinès organizacijos raidos stimuliuojančia jèga pripažintas gyventojų skaičiaus augimas, kuris, remiantis teoriniais skaičiavimais, I-XVI a. tolygios evoliucijos laikotarpiais vidutiniškai siekè 0,1 proc. / metus [52, 400]. Pažymėtina, kad gyventojų skaičius bendrajame socialinès organizacijos proceso modelyje yra ne tik atskaitos taškas, bet ir viso ciklo rezultatas, taigi esant tolygiai evoliucijai, pasikeitusi socialinè organizacija turètų paskatinti „demografini šuolį“, kuris stimuliuoja modeliuojamo ciklo pasikartojimą kokybiškai aukštesniu lygiu (spirale), iš naujo tolygiai didindamas gyventojų skaičių. Modeliuojamą procesą gali sutrikdyti ịvairūs mutacijos veiksniai (badmečiai, priešų antpuoliai, epidemijos), kurie paprastai daro poveiki populiacijos dydžiui (dalis bendruomenių sunaikinamos), pažeisdami (kartais iš esmès pakeisdami) socialinès organizacijos raidą.

Siekdami nustatyti galimą maksimalų gyventojų skaičių ir jo kaitą konkrečiame Dubingių mikroregione tolygios evoliucijos laikotarpiais galime pasinaudoti teoriniais mikroregiono ploto skaičiavimais [29], konkrečiam laikotarpiui būdinga žemdirbystès sistema, ùkininkavimo intensyvumu bei Vita-Finzi, Higgs ir Carneiro formule (4) [73, 56]. Šie skaičiavimai pateikiami 1 lentelèje.

Teoriškai apskaičiuojant galimą Dubingių mikroregiono gyventojų skaičių naudojami XVI a. žemdirbystès duomenys [38, 106-121; 19, 53-63; 50, 74-75], kurie tikrai nebuvo prastesni nei geležies amžiuje ar ankstyvaisiais viduramžiais. Formulèje liko neįskaičiuotas žemès derlingumas, kuris Dubingių mikroregione buvęs mažesnis nei vidutinis Lietuvoje [35], tad galètų tik sumažinti pateiktus gyventojų skaičius.

(4) Formulejje gyventojų skaičius = bendram ariamam plotui hektarais, padaugintam iš žemès kultivavimo laikotarpio metais / žemės ploto, reikalingo vienam žmogui prasimaitinti vienerius metus, padaugintam iš žemès pūdymavimo laikotarpio metais + žemès kultivavimo laikotarpio metais. Dubingių mikroregiono atveju bendras ariamos žemès plotas hektarais susiejamas su viso mikroregiono plotu ir galima ariamo ploto dalimi iš viso mikroregiono ploto (nuo 5 iki 100 proc.). Tokiu atveju ariamos žemès plotas būtų 875 ha, 1750 ha, 5250 ha, 8750 ha ir 17500 ha. Greta šių dydžių gyventojų skaičius papildomai skaičiuojamas pagal iš rašytinių šaltinių žinomą dirbamos žemès plotą Dubingių parapijoje $1690 \mathrm{~m}$. ir valsčiuje 1634 metais. Žemès kultivavimo skirtingomis žemdirbystès sistemomis laikotarpis metais buvo skaičiuojamas remiantis literatūra $[75 ; 81]$. Šių autorių teigimu, žemès lydiminėje žemdirbysteje 4 metų ištisinị žemès kultivavimą keitè ne trumpesnè kaip 50 metų pertrauka. Dvilauke sejomaina grịstos ariamosios žemdirbystės atveju kasmet buvo dirbama $1 / 2$ ariamos žemès, o kita paliekama pūdymui. Po kelių tokių ciklų žemè nusialindavo ir buvo paliekama dirvonuoti iki 1520 metų, dèl to skaičiuojant buvo remtasi 2,5 metų žemès arimo ( 5 metai po $1 / 2$ lauko) $+12,5$ metų dirvonavimo (įskaitant 5 metų dirbimo laiką, kai pūdymavo po 1/2 lauko) ciklu. Trilaukès žemdirbystès atveju prisilaikyta gyvenviečių stabilumo prielaidos, pagal kurią kasmet buvo dirbama $2 / 3$ žemès, o $1 / 3$ paliekama pūdymui, taigi žemès kultivavimo laikotarpis sudarè 0,66 , o pūdymavimo - 0,33 metų . Tikrovè galëjusi būti kiek prastesnè, nes žinoma, kad nepakankamai patręšus mëšlu, trilaukè sèjomaina taip pat nualina dirvožemį, todèl tenka ji palikti dirvonuoti iki 10 metų $[10,123]$. Žemès plotas, reikalingas vienam žmogui prasimaitinti vienerius metus, buvo skaičiuojamas atsižvelgiant i H. Lowmianskio pateikiamą šeimos dydị - 6 žmonès 1 dūmui Vilniaus vaivadijoje $[38,109]$ ir iš XVI a. žinomą valakų ir dūmų santykị Dubingių mikroregione, kur 1 valake vidutiniškai buvo 1 dūmas [19, 53-63]. Tai reikštų, kad vienas dūmas išgyveno iš maždaug 21,36 ha, arba po 3,6 ha kiekvienam žmogui. Kitas galimas skaičiavimo variantas remtųsi $\mathrm{H}$. Lowmianskio pateikiamu valako ir dūmo santykiu [38, 114], pagal kurị vienas žmogus galejęs išgyventi iš 2,17 ha ploto. Šie du skirtingi žemès ploto, reikalingo vienam žmogui prasimaitinti vienerius metus, dydžiai lèmė, kad atlikus skaičiavimą buvo gautas gyventojų skaičiaus intervalas. 
1 lentelè. Maksimalus galimas Dubingių mikroregiono gyventojų skaičius, kai mikroregiono plotas lygus 175 km², 01 žmogui per metus išgyventi reikia vidutiniškai 2,17-3,6 ha žemès

\begin{tabular}{|c|c|c|c|}
\hline \multirow[b]{2}{*}{ Žemdirbystės intensyvumas } & \multicolumn{3}{|c|}{ Žemdirbystės sistema } \\
\hline & Lydiminè & $\begin{array}{l}\text { Ariamoji } \\
\text { dvilauké }\end{array}$ & $\begin{array}{l}\text { Ariamoji } \\
\text { trilauké }\end{array}$ \\
\hline $\begin{array}{c}\text { Dirbamos žemės sudaro } 100 \text { proc. } \\
\text { visos žemės ploto }\end{array}$ & $360-597$ & $810-1344$ & $3241-5376$ \\
\hline $\begin{array}{l}\text { Dirbamos žemés sudaro } 50 \text { proc. } \\
\text { visos žemés ploto }\end{array}$ & $180-299$ & $405-672$ & $1620-2688$ \\
\hline $\begin{array}{c}\text { Dirbamos žemės sudaro } 30 \text { proc. } \\
\text { visos žemės ploto }\end{array}$ & $108-179$ & $243-403$ & $972-1612$ \\
\hline $\begin{array}{l}\text { Dirbamos žemės sudaro } 10 \text { proc. } \\
\text { visos žemès ploto }\end{array}$ & $36-60$ & $81-134$ & $324-537$ \\
\hline $\begin{array}{c}\text { Dirbamos žemès sudaro } 5 \text { proc. } \\
\text { visos žemès ploto }\end{array}$ & $18-30$ & $40-67$ & $162-268$ \\
\hline $\begin{array}{l}\text { Dubingiụ parapijos dirbamos žemès plotas } \\
\qquad 1690 \mathrm{~m}^{2} \text { (apie } 5212 \mathrm{ha} \text { ) }\end{array}$ & $107-178$ & $241-400$ & $965-1601$ \\
\hline $\begin{array}{l}\text { Dubingiu dvaro valsčiaus dirbamos žemès } \\
\text { plotas } 1634 \mathrm{~m}^{2} \text { (apie } 4919 \text { ha) }\end{array}$ & $101-168$ & $228-378$ & $911-1511$ \\
\hline
\end{tabular}

Viso mikroregiono ploto ir dirbamos žemès santykị taip pat galime bandyti nustatyti iš vèlesnio laikotarpio dokumentų. $1634 \mathrm{~m}$. inventoriaus duomenimis, dirbamos žemès plotas sudarè tik apie 10 proc. visos Dubingių kunigaikštystės teritorijos [27, 31-32], o per visą XVII-XVIII amžių Radvilų Dubingių kunigaikštystėje bei Dubingių parapijoje dirbamos žemės plotai niekada neviršijo 10-15 proc. bendros teritorijos [27, 32-39]. XIX a. viduryje Vilniaus apskrityje ariama žemė sudarẻ 32 proc., o Švenčionių apskrityje - tik 22 proc. bendros teritorijos $[76,431]$. Taigi, modeliuojant galimą mikroregiono gyventojų skaičių, labiausiai tikètini duomenys pateikti eilutèje „dirbamos žemės sudaro 10 proc. visos žemès ploto“. Empirinių duomenų apie mikroregiono gyventojų skaičių turime tik iš XVI-XVII a. pradžios. Šio laikotarpio dokumentuose dažniausiai pateikiamas tik tarnybų ir dūmų skaičius, o gyventojų skaičius yra išvestinis, skaičiuojamas remiantis H. Lovmianskio nustatytais $[38,110]$ tarnybos - dūmo ir žmonių skaičiaus tarpusavio kiekybinio santykio rodikliais. Pagal ankstyviausią Dubingių dvaro gyventojų sąrašą (datuojamą 1510-1523 m.), Dubingių dvare galejo gyventi apie 500 asmenų. Radvilų dvarų 1528 m. inventoriaus duomenimis [47, 181-182], Dubingių dvare galèjo gyventi 966-1 203 žmonès, Baranavos dvare - 18 žmonių, Žaugèdų dvare - 32-41 žmogus. 1554 m. inventoriaus duomenimis [19, 53-63], Dubingių vaitijoje (5) galèjo gyventi apie 318 žmonių, o $1634 \mathrm{~m}$. Dubingių dvaro valsčiuje gyveno apie 1962 žmonès. Toks santykinai nedidelis mikroregiono gyventojų skaičius svarbus ịvertinant ūkininkavimo galimybès (nedaug žmonių, daug laisvos žemės, dideli atstumai tarp bendruomenių) ir modeliuojant mutacinių veiksnių poveikị. Dèl menko gyventojų skaičiaus priešų antpuoliai, badmečiai ar epidemijos Dubingių mikroregiono socialinę raidą galèjo pažeisti kur kas labiau nei tankiai apgyvendintų regionų. Dèl mutacijos veiksnių mikroregiono

(5) Šiam teritoriniam vienetui priskiriami dabartiniai Vilniaus r. sav. esantys Troškūnų, Daukšių, Grybėnų, Tarakonių kaimai ir buvęs Daukšènų kaimas bei iš XIX a. kartografijos žinoma Gejènų dvarvietė; dabartiniame Švenčionių r. esantis Matakiemio kaimas, prie Laumeno ežero buvęs Gelcevičiavos kaimas ir prie Dubingių ežero buvę Staniučių ir Pavilių kaimai. 
teritorija galèjo lengvai virsti dykra, kurios atkūrimui būtų reikejję vidinės kolonizacijos (gyventojų perkèlimas iš kitų LDK vietovių).

Tolygios evoliucijos laikotarpiais gyventojų skaičiaus augimas skatino ūkininkavimo pokyčius, nes augančiai bendruomenei reikia daugiau maisto. Galime manyti, kad iš pradžių maisto kiekis didinamas pasitelkiant vidinius bendruomenès resursus: plečiamas medžioklès arealas, didinami pievų, dirbamos žemės plotai. Tokie kiekybiniai (ekstensyvūs) pokyčiai nedidelėse bendruomenėse buvo labai riboti, jiems reikèjo didelių papildomų darbo ir laiko sąnaudų, todèl pakankamai greitai turèjo būti pasiekiama ekstensyvios ùkininkavimo plètros riba. Augančio gyventojų skaičiaus maisto poreikius galima patenkinti tik įdiegus naujoves, kurios galimos tiek dẻl visuomenès atliktų vadinamųjų paralelinių atradimų, tiek dèl dviejų visuomenių komunikacinès (difuzinio pobūdžio) sąveikos [55, 11-34]. Inovacijų požiūriu Rytų Lietuva vertintina kaip i̇vairialypis regionas. Viena vertus, šiaurès pietų geopolitinė orientacija, regioną kertantys prekybos keliai, pakankamai intensyvūs lietuvių genčių (vèliau LDK) karo žygiai ị gretimas teritorijas bei valstybès sostinès Vilniaus iškilimas turèjo skatinti inovacijas, tačiau, kita vertus, nuo $\mathrm{X}$ a. (po Rusios ir Lenkijos krikšto) pagoniškos lietuvių teritorijos (vèliau LDK) atsidūrè vis didesnejje politinejje ir kultūrinèje izoliacijoje ir tapo savotišku „inovacijų užribiu.“ Inovatyvumo situaciją dar labiau sunkino rašto ir formalaus ugdymo sistemų nebuvimas pagoniškoje visuomeneje. Dèl tokios situacijos valstybès ir visuomenès raida lètejo, kartu igydama specifinių bruožų, nebūdingų nei bizantinei, nei katalikiškai civilizacinei erdvei. Tai leidžia kalbėti apie ankstyvojo valstybingumo laikų ir LDK visuomenès bei valstybès raidos modelio specifiką, kuris greta despotiško bizantinio ir korporatyvaus katalikiško gali būti įvardijamas kaip savitas viduramžių Europos socialinių tyrimų objektas, o LDK viduramžių visuomenè (apskritai LDK viduramžiai) nagrinejjama kaip savarankiškas ir specifinis fenomenas, susiformavęs pagoniška pasaulěžiūra grịstoje intensyvių bizantinès krikščionybės ir katalikybès sąveikų erdvèje.

Diegiamos inovacijos ir augantis gyventojų skaičius skatino ekonominius pokyčius, Lietuvos atveju - didino žemdirbystès reikšmę bendroje ūkininkavimo struktūroje, lètino žemès nualinimo procesus ir mažino bendruomenių mobilumą. Lietuvoje ekonominè raida ir jos sukelti pokyčiai priklausė nuo dirvožemio derlingumo - spartesni geresnių dirvožemių regionuose ir lètesni ten, kur dirvožemiai buvo prastesni. Nusistovint kaimavietėms susiformavo senụjų kelių tinklas, lengvinęs bendruomenių tarpusavio komunikaciją bei išorinę prekybą. Inovacijų poreikis ir augantis gyvenviečių stabilumas skatino du svarbius koncentracijos ir ịvairovès veiksnius, kurie, pagal Gerto Jano Hosperso kūrybinių erdvių (miestų) formavimosi teoriją, sudaro sąlygas vienoms geografinèms erdvèms igyti pranašumą prieš kitas [29]. Taip atsiranda centralizuotas visuomenès valdymas, stiprèja centralizuota valdžia. Viena vertus, augantys derliai skatina visuomenès turtinę nelygybę, kita vertus, sukuriama pridedamoji vertè leidžia išlaikyti administraciją (žmones, kurie tiesiogiai neūkininkauja, bet atlieka kitas socialines, pavyzdžiui, saugumo užtikrinimo, funkcijas). I. Prigogine’o sistemų teorijos požiūriu [48, 27-31] centralizuota ir gerai administruojama sistema yra atsparesnė mutaciniams poveikiams ir greičiau atsikurianti po neišvengiamų mutacijų nei menkai centralizuota sistema. Taigi hipotetiškai galime teigti, kad valdymo centralizacija sukuria palankesnes sąlygas gyventojų skaičiaus augimui, nei tai vyktų decentralizuotoje visuomenèje, todèl bendrasis socialinès organizacijos procesas vyksta intensyviau ir gali kartotis kokybiškai aukštesniu lygmeniu. Taip pat galime kelti hipotezę, kad nederlinguose regionuose įsikūrusioms negausioms ir mutaciniam poveikiui mažiau 
atsparioms bendruomenėms valdymo centralizacija buvo svarbesnè išlikimo sąlyga nei turtingụjų regionų bendruomenèms, ir tai galèjo tapti vienu iš svarbių veiksnių lietuvių gentims kuriant Lietuvos valstybę.

Be šių deterministinio pobūdžio sąsajų, bendrojo visuomenès socialinės organizacijos proceso teorinio modelio elementai gali būti susiję ir tiesioginiais ryšiais, pavyzdžiui, centralizuota valdžia gali skatinti ūkininkavimo kaitą administraciniu būdu (XVI a. viduryje Valakų reformos metu valstybiniuose dvaruose buvo įvesta privaloma trilaukè sėjomaina) ar įveždama naujas gyvulių bei augalų veisles (žinoma, kad XVII a. ị Radvilų dvarus buvo atvežta olandiškų galvijų). Lygiai taip pat, pavyzdžiui, siekdama efektyvesnio mokesčių surinkimo ir administravimo centralizuota valdžia gali stabdyti bendruomenių mobilumą ir skatinti kurti stabilias gyvenvietes prie konkrečių prekybai svarbių kelių arba, atvirkščiai, dèl vidinès kolonizacijos skatinti gyventojų perkèlimą iš vienos vietos ị kitą.

Konkrečios bendruomenès raida, vykstanti pagal bendrąji socialinės organizacijos proceso modelį, gali būti traktuojama kaip spiralinė, pakartojanti bendrojo modelio etapus kiekvieną kartą vis kitu kokybiniu lygmeniu. Konkretaus Dubingių mikroregiono bendruomenès raidos modelis pateikiamas 2 -ame paveiksle.

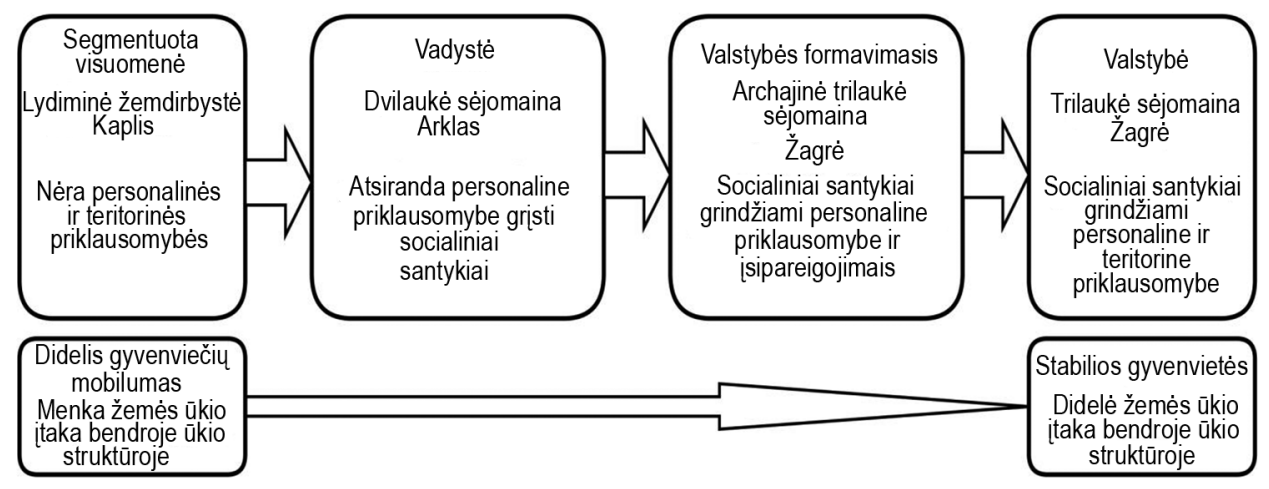

2 pav. Mikroregiono bendruomenés raidos modelis I a. $-\mathrm{XVI}$ a. viduryje

Schemoje pateikiamus bendruomenès raidos etapus galime nagrinèti įvairiais pjūviais, siedami juos su bendrojo socialinès organizacijos proceso modelio schema. Teoriniame tyrime baziniu pasirinktas neomarksizmo filosofijai būdingas požiūris ị ekonominių sąlygų išskirtinę svarbą visuomenès raidai [52, 415-430]. Galima teigti, kad visuomenès raidos mikroregione pagrindu buvo ūkininkavimo forma ir sukuriama ekonominè pridedamoji vertè, o kaitos varikliais - kokybiniai ekonominès veiklos pokyčiai bei vietinès socialinès gamtinès sistemos sukrètimai („mutacijos“). Straipsnyje mikroregiono socialinès organizacijos raida modeliuojama remiantis ekonominès veiklos formų kaita (mikroregiono ekonomine raida). Išskiriami mažiausiai trys I-XVI a. Dubingių mikroregiono ekonominès ir socialinès raidos chronologiniai laikotarpiai: pirmasis - lydiminès žemdirbystès, antrasis - ariamosios, dirvoninès ir dvilauke sejomaina pagrịstos žemdirbystès ir trečiasis - ariamosios, trilauke sejomaina pagrịstos žemdirbystès (6).

(6) Ekonominis šios chronologijos pagrindimas pateikiamas autoriaus straipsnyje „Dubingiu mikroregiono ekonominès raidos specifika I a. - XVI a. viduryje“ [35]. 


\section{SOCIALINIS KAPITALAS PRAEITIES VISUOMENĖJE}

Socialinio kapitalo sąvoka yra pakankamai plačiai naudojama mokslinèje literatūroje ir viešojo administravimo erdvejje, tačiau jos turinys dažnai neatskleidžiamas ar atskleidžiamas prieštaringai. Socialinio kapitalo termino kūrèjas L. Judsonas Hanifanas ji taip apibrèžè: „...vartodamas terminą socialinis kapitalas aš neturiu galvoje iprastos kapitalo sampratos... <... $>$.. aš nekalbu apie nekilnojamąji turtą, asmens nuosavybę ar grynuosius pinigus, bet kalbu apie tai, kas šiuos materialius dalykus paverčia kasdieninio gyvenimo vertybėmis, kaip antai: gera valia, draugystė, abipusè simpatija ir socialiniai ryšiai, kurie leidžia atsirasti socialiniams vienetams..." $[17,130]$. Šis apibrěžimas vaizdžiai rodo socialinio kapitalo turinį, bet siekdami paversti socialinio kapitalo tyrimus mokslinių tyrimų objektu turime ịtraukti formalesnius apibrěžimus bei išskirti aiškesnius kriterijus. Tai buvo atlikta informacijos komunikacijos teorijų kontekste socialinio kapitalo funkcionavimą suvokiant per bendruomenès narių informacijos mainus, komunikaciją ir vartojant socialinių interakcijų terminą. Socialinès interakcijos šiame kontekste buvo suprantamos kaip „...išorinès formos, kurių dèka kažkurios grupès veiksmai siejami su asmens pasirinkimais <...> ką vadiname "kažkuriomis grupemis“ priklauso nuo konteksto, tai gali būti šeimos, kaimynai, draugai ar socialiniai sluoksniai $<\ldots>$ socialinès interakcijos kartais dar vadinamos „ne-rinkos“ sąveika, siekiant pabrèžti faktą, kad jos nèra reguliuojamos kainų mechanizmo..." $[58,1-2]$. Socialinių interakcijų atžvilgiu grindžiama Pasaulio banko socialinio kapitalo koncepcija: „...socialinis kapitalas apibrèžia visuomenès institutus, ryšius ir normas, kurie sąlygoja socialinès sąveikos kiekybę ir kokybę... <...> ...tai yra aibè horizontalių žmonių tarpusavio sąsajų, sudarančių socialinius tinklus..." [60]. Toks apibrèžimas, susietas su socialinių mokslų eksploatuojama tinklaveikos idèja, sukuria visuomenès tinklaveika grịstą požiūrị ì socialinį kapitalą. Kaip teigia vienas žymiausių šiuolaikinių socialinio kapitalo teoretikų Robertas D. Putnamas, „...socialinio kapitalo teorijos branduolys ir idejja yra ekstremaliai paprasti: visuomenès tinklaveika..." $[49,100]$; čia tinklaveika suprantama kaip socialinių interakcijų ir žmonių tarpusavio asmeninių ryšių tinklas [41] (7). Pasak R. D. Putnamo, tinklaveika pirmiausia sukuria vertę tiems žmonėms, kurie yra tinklo dalis, pavyzdžiui, turint pažistamų kur kas yra lengviau susirasti darbą. Kita vertus, tinklaveika sukuria ir išorinę pridedamąją vertę: „geros kaimynystės“ bendruomenėse nusikalstamumo lygis yra mažesnis. Tinklaveika gali būti formalizuota (kaip klubas) ar neformali (kaimynų bendravimas), grịsta stipriais ar silpnais asmeniniais ryšiais,

(7) Tačiau būtina pažymèti, kad visuomenès tinklaveikos reiškinio buvimas pats savaime nereiškia, kad kalbame apie tinklaveikos visuomenę [8, 5-10]. Šiuo atveju galètume pasinaudoti panašia schema, kurią Manuelis Castellsas pritaiko aptardamas informacijos funkcionavimą visuomeneje ir semantiškai atskirdamas „informacijos“ ir „informacinio“ požymius. Anot mokslininko, „...sąvoka „informacijos“ pabrěžia informacijos vaidmenį ir reikšmę visuomenei..." Tai leidžia „informacijos“ semantinị lauką atsieti nuo technologijų ir chronologinių laikotarpių. Informacija ir jos mainai buvo svarbūs visais žmonijos istorijos laikotarpiais ir šiuo požiūriu XXI a. nesiskiria nuo kitų. „....Sąvoka „informacinis“ žymi specifinei socialinès organizacijos formai būdingą bruožą, kai dèl pasikeitusių technologinių sąlygų ir socialinès aplinkos informacijos kūrimas, apdorojimas ir perdavimas tampa pagrindiniais produktyvumo ir galios šaltiniais..." Taigi informaciniai reiškiniai susiejami su skaitmenine technologija ir tampa būdingi tik šiuolaikinei visuomenei $[8,149-154]$. Pritaikydami tą pačią schemą visuomenès tinklaveikai turime pažymèti, kad asmeniniais ryšiais ir socialinėmis interakcijomis grịsta tinklaveika yra nepriklausoma nuo chronologinio laikotarpio, ji būdinga visų laikų visuomenèms. Specifinès tinklaveikos visuomenès asmeniniai ryšiai ir socialinės interakcijos susiformuoja tik skaitmeninių technologijų ir jomis grịstų kompiuterinių tinklų dèka ir tai yra XX a. pabaigos - XXI a. pradžios socialinès organizacijos forma. 
intravertiška ar ekstravertiška, socialiai uždara (kaip religinė sekta) ar socialiai atvira (kaip jau minètas klubas) [49, 63]. Per visuomenès tinklaveiką užtikrinama grupès ir pavienių asmenų / kelių grupių tarpusavio interesų derinimas ịvairiose veiklose bei bendras išteklių (materialių ir nematerialių) naudojimas derinant skirtingus interesus. Tai paprastai atliekama pasitelkiant vienokias ar kitokias socialines struktūras ir jų narių veiksmus tų struktūrų viduje [9, 96-101], visiems suprantamas (moralès) normas, sankcijas už jų nevykdymą bei reguliuojant informacijos srautus [44, 2-3].

Socialinio kapitalo teorijos kaip metodologinès nuostatos taikymas praeities visuomenių tyrimui yra sąlygotas hipotetinio suvokimo, kad be socialinio kapitalo visuomenès funkcionavimas yra neịmanomas. Taigi praeities visuomenès taip pat turëjo generuoti socialinio kapitalo pridedamąsias vertes. Tačiau tokius tyrimus sunkina skirtingos šiuolaikinių socialinio kapitalo tyrimų ir praeities visuomenių tyrimų empirinių duomenų rinkimo metodikos bei galimybès. Sociologijos metodika, grịsta empirinių duomenų rinkimu iš šiuolaikinių funkcionuojančių visuomenès struktūrų, taip pat tinklų ir individų anketavimo, giluminio interviu ir kiti sociologijos metodai [60] iš esmès netinka praeities (nebeegzistuojančioms) visuomenèms ir individams. Tirdami praeities visuomenių socialinị kapitalą turime žengti žingsnelị atgal - atsiriboti nuo sociologijos empirinių duomenų rinkimo metodų ir susieti tyrimą su socialinio kapitalo formaliosiomis apibrež̌timis bei istorinių procesų modeliavimo patirtimi. Šiuo požiūriu svarbiausiu socialinio kapitalo analitiniu vienetu tampa visuomenès tinklaveika [43, 15-18], išreikšta per visuomenès narių asmeninius ryšius ir socialines interakcijas. Nors šie abu elementai yra komunikacinio pobūdžio, o kai kurie autoriai socialinę interakciją ir asmeninius ryšius laiko sinoniminiais, praeities tyrimų kontekste turètume juos skirti. Asmeninių ryšių ir socialinės interakcijos poroje pirmasis elementas yra pasyvus, o antrasis - aktyvus. Žmonių asmeniniai ryšiai gali būti apibūdinami kaip dviejų ar daugiau asmenų tarpusavio santykis, grịstas bendrumu, meile, solidarumu, profesine sąveika ir pan. Svarbiausias asmeninių ryšių požymis yra poveikio potencialas, tai yra potenciali galimybè vienam asmeniui natūraliai, be prievartos daryti poveiki kitam asmeniui (pavyzdžiui, natūraliai keičiantis vienam asmeniui tai gali tapti ir kito asmens kaitos priežastimi). Tokie ryšiai apibūdinami kaip holistiniai (nepriklausomi nuo erdvès ir laiko). Svarbu pažymèti, kad asmeniniai ryšiai turi būti skiriami nuo formaliųjų, kurie yra sąlygoti socialinės padèties, galių skirtumų, darbo santykių ir yra fragmentiški, vykstantys tik atitinkamoje vietoje ir atitinkamu laiku [69, 769-790]. Dèl šios priežasties bajoro ir jo baudžiauninko ar viršininko ir jo pavaldinio ryšių negalime vadinti asmeniniais ryšiais. Kaip jau minèta, asmeniniai ryšiai paprastai yra pasyvūs ir suaktyvinami tik per socialines interakcijas. Patikslinant anksčiau pateiktą socialinių interakcijų apibūdinimą reikia nurodyti, kad socialinės interakcijos apibrèžiamos kaip dviejų ar daugiau žmonių bendri aktai, veiksmai, praktikos ar bet koks kitoks elgesys, kuriuo siekiama paveikti ar suderinti kitų asmenų ar grupių patirtị bei ketinimus. Socialinè interakcija reiškia, kad kiekvienas jos dalyvis žino apie kitus dalyvius, juos personalizuoja, turi savo mintyse ir tam nebūtina tiesioginè sąveika. Draugai gali rašyti vienas kitam laiškus, kariaujančių šalių generolai gali rengti ir vykdyti vieni prieš kitus nukreiptus karo planus, verslo konkurentai gali sąmoningai ignoruoti vienas kitą. Socialinė interakcija neapibrèžiama fiziniu ryšiu, elgesio formomis ar fiziniu atstumu, svarbiausias jos bruožas yra „kitos pusès“ personalizacija ir sąmoningi abipusiai interakcijos dalyvių veiksmai. Socialinè interakcija nevyksta tuo atveju, jei vienas sąveikos dalyvių nežino apie kito veiksmus (pvz., šnipinejjimas) ar vienas dalyvis traktuoja kitą kaip fizinį (nepersonalizuotą) objektą 
(pavyzdžiui, budelio ir aukos, prižiūrètojo ir kalinio, nusikaltèlio ir nukentėjusiojo santykiai). Tokios (prievartinès ar neịsisąmonintos) socialinès interakcijos nekuria socialinio kapitalo pridedamųjų verčių [56].

Šie du visuomenès tinklaveikos požymiai (asmeniniai ryšiai ir socialinès interakcijos) gali būti iš dalies pamatuojami panaudojant mūsų turimus archeologijos ir istorijos empirinius duomenis apie praeities visuomenes. Socialinio kapitalo teorijos pritaikymas praeities visuomenių tyrimui leidžia geriau pažinti tų visuomenių socialinę organizaciją ir jos funkcionavimo mechanizmą, paaiškinti sąsajas tarp bendruomenès vykdomos ūkinès veiklos, kasdieninio gyvenimo normų, ritualų, religinio pobūdžio praktikų, administracinių struktūrų veiklos ir jų santykio su bendruomenèmis. Straipsnyje analizuojant socialinès organizacijos raidą mikroregione vadovaujamasi 3 pav. pateikiamu skirtingų socialinių struktūrų sąveikos teoriniu modeliu.

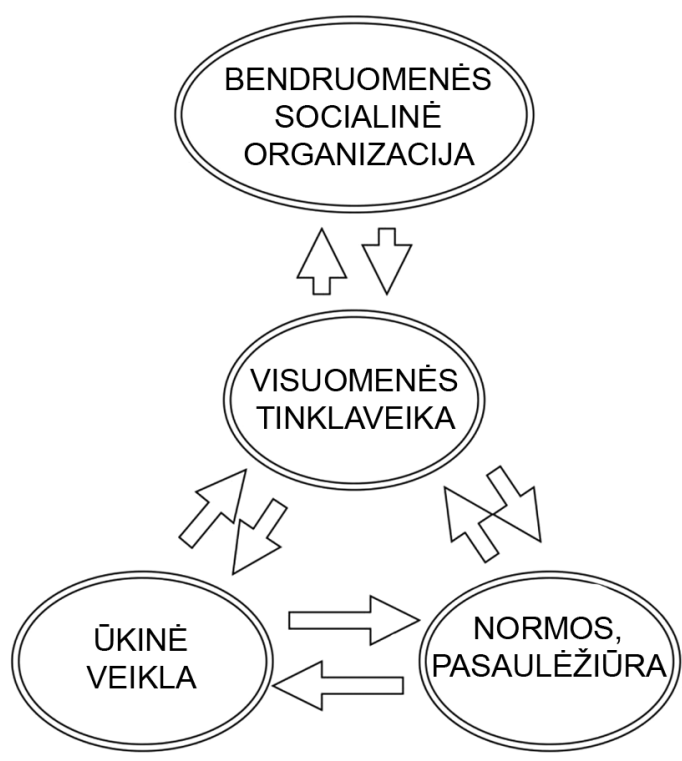

3 pav. Socialinės organizacijos, visuomenės tinklaveikos, ekonomikos ir socialinių normų sąsajos

Pateiktame modelyje pagrindiniu socialinę organizaciją lemiančiu veiksniu įvardijama visuomenès tinklaveika, kuri savo ruožtu sąveikauja su ūkine veikla ir visuomenejje įsigalejjusiomis normomis bei pasaulèžiūra. Socialinių struktūrų bei struktūrų ir socialinès organizacijos ryšiai yra abipusiai, tai yra modelyje vengiama taikyti tiesioginio determinizmo principą. Tolesniame straipsnio tekste, analizuojant socialinio kapitalo ir socialinès organizacijos raidą, nesiekiama aptarti visų i̇manomų modelio ryšių ir jų variacijų. Kadangi straipsnio tikslas yra Dubingių mikroregiono bendruomenès socialinès organizacijos modelio pagrindimas, dauguma analizuojamų ryšių ir poveikių yra vienakrypčiai. Tai reiškia, kad daugiau domimasi, koki poveiki, pavyzdžiui, ūkinè veikla turi visuomenès tinklaveikai ir per ją - bendruomenès socialinei organizacijai, nei, pavyzdžiui, koki poveikị visuomenès tinklaveika turi ūkinei veiklai. Straipsnio pradžioje pasirinkta metodologinè paradigma bei daugiau materialinę praeities visuomenių kultūrą atspindintys I-XVI a. empiriniai duomenys stumia tyrimą lengvo determinizmo kryptimi, kai išeities tašku 
pasirenkama ūkinè veikla, skatinanti permainas visuomenės normų ir pasaulèžiūros erdvejje bei lemianti visuomenès tinklaveiką.

\section{SOCIALINĖS ORGANIZACIJOS RAIDA PIRMUOJU LAIKOTARPIU (I-II, IV a.)}

Pirmuoju laikotarpiu vyravusi ūkinès veiklos struktūra skatino visus bendruomenès narius veikti kartu siekiant išgyventi, bendruomenès buvo nedidelès, pakankamai mobilios ir išsibarsčiusios dideliuose plotuose, skirtingų bendruomenès narių (grupių) socialinė diferenciacija nebuvusi ryški, o paskiro individo ar nedidelès šeimos išgyvenimo galimybès atskirai nuo bendruomenès buvo menkos. Dèl bendrų veiklų ir santykinai nedidelio bendruomenès narių skaičiaus (apie 20-30 asmenų) asmeniniai ryšiai bendruomenès viduje turèjo būti labai stiprūs, o dẻl didelių atstumų tarp bendruomenių šie ryšiai už bendruomenès ribų - decentralizuoti ir silpni. Dèl neryškios socialinès diferenciacijos asmeniniai ryšiai buvo vien horizontalūs (nehierarchiniai). Bendruomenės viduje vykusios socialinès interakcijos taip pat buvo horizontalios. Jos turejo būti stipriausios asmeniniu lygmeniu, nes mažoji šeima (kaip asmenų grupè) dar nebuvo tapusi ịtakingu socialiniu vienetu. Socialinès interakcijos tarp skirtingų bendruomenių taip pat turejjo būti horizontalios. Jos buvo silpnos, ritualinio (bendros šventès, vedybų ryšiai ar pan.) ar ekonominio (resursų mainai) pobūdžio (8). Socialinès interakcijos su geografiškai nutolusiomis bendruomenėmis (kitų kultūrų žmonėmis) buvo atsitiktinès. Šiuo požiūriu romėniškuoju laikotarpiu suintensyvėjusius prekybos santykius su nutolusiomis bendruomenèmis (pavyzdžiui, gintaro prekybą su Romos imperija ar pagausėjusius Vidurio Europai būdingus radinius Rytų Lietuvoje [80, 95-104]) kažin ar galime laikyti socialinių interakcijų išdava. Romėnams, kaip ir šiaurinių Romos kolonijų (ar vėliau arabų) pirkliams, Baltijos pajūrio ar Neries pakrančių gyventojai buvę depersonalizuoti - tiesiog „aisčiai.“ Romènų šaltiniuose nèra išlikę jokios informacijos apie aisčių „personalizaciją“ (nenurodomi jokių konkrečių asmenų asmenvardžiai), o germanai ir galai jau buvę personalizuoti (Gajaus Julijaus Cezario „Galų karo užrašuose“ paminèti vadų vardai - Vercingetoriksas, Ariovistas). Asmeninių ryšių ir socialinių interakcijų specifika suformuoja pirmajam laikotarpiui būdingą visuomenès tinklaveiką, kurios svarbiausias bendrasis požymis yra horizontalių asmeninių ryšių ir interakcijų vyravimas, bendruomenių homogeniškumas ir uždarumas, nedidelè geografinė aprèptis. Horizontalios tinklaveikos vyravimas nereiškia, kad pirmojo laikotarpio visuomenė priminè komuną be lyderių ar administravimo. Priklausymas grupei ir paklusimas hierarchijai didino bendruomenès socialinį kapitalą, grupès atsparumą mutacinio pobūdžio poveikiams ir galimybes išlikti. Tačiau, skirtingai nei vèlesniais laikotarpiais, pirmojo laikotarpio grupès lyderystẻ buvusi bene labiausiai natūrali, priklausoma nuo asmeninių gebejjimų ir neturinti korporacinio uždarumo bruožų, o bendruomenès nariai traktuotini kaip laisvi nuo priverstinès teritorinès ar asmeninès priklausomybès. Socialinio bendruomenių kapitalo didžiausios vertės turejo būti kuriamos nedidelių bendruomenių viduje, bendruomenių išoriniai ryšiai turèjo kurti tik nedidelę

(8) Skirtingų bendruomenių socialinių interakcijų požiūriu gali būti ịdomūs tyrimai, siejantys šias interakcijas ir kalendorines šventes. Bažnytiniai atlaidai, kaip skirtingų bendruomenių susitikimų vieta Lietuvoje, buvo svarbūs dar XIX a. pab. - XX a. pr. Vienas svarbių tokių susitikimų aspektų galëjo būti santuokinių ryšių užmezgimas, nes nedidelèms ir nutolusioms bendruomenèms santuokiniai ryšiai tik su savos bendruomenès asmenimis būtų pražūtingi. Su astronominiais ciklais (saulègrižos, lygiadieniai) susietos kalendorinès šventès, kurių metu nutolusių bendruomenių nariai susirenka vienoje vietoje, žinomos ịvairiose kultūrose. Lituanistinių tyrimų erdveje šiuo požiūriu būtų ịdomus sakmių grupès apie raganų susirinkimus ant Šatrijos kalno Joninių naktị tyrimas [57]. 
socialinio kapitalo dalị. Tai turèjo sąlygoti labai lètą evoliucijos tempą, visuomenès konservatyvumą, nedideli inovacijų kiekį, tačiau kartu tokios bendruomenès vidinès sutelkties dèka turejo būti labai atsparios įvairiems sukrètimams, „mutacinio“ pobūdžio situacijoms. Toks (uždaras, atribotas) socialinio kapitalo kūrimo mechanizmas iš dalies galètų paaiškinti praeities kultūrų teritorinių ir laiko aprèpčių kaitą. Bendroji tendencija yra ta, kad ankstesnių laikų archeologinès kultūros apėmė didesnes teritorijas ir chronologiškai ilgesnius laikotarpius nei vèlesnių laikų archeologinès kultūros.

Visuomenès tinklaveika ir socialinis kapitalas suformavo pirmajam laikotarpiui būdingą socialinę organizaciją, kuri galètų būti įvardyta kaip segmentuotos visuomenès $[52,174-189]$ atmaina. Segmentuotų visuomenių bruožų bei savybių apibrèžimas mokslinejje literatūroje yra pakankamai skirtingas, neretai painiojamas su genties ir vadystès apibrěžimu, todèl verta atkreipti dèmesị ị šios tematikos klasikines Emilio Durkheimo [12], Kalervo Obergo [45, 472-487] bei Elmano Rogerso Service’o [52, 154-156] publikacijas. Anot E. Durkheimo, segmentiškumas nusako visuomenès struktūrą, sudarytą iš elementų (segmentų), kurių kiekvienas yra panašus ị kitą. Taigi ir visuomenę sudaro įvairios socialinès grupès (segmentai), panašios struktūriniu požiūriu. Tai reiškia, kad asmenys iš skirtingų segmentų turi daugiau ar mažiau vienodas galimybes užimti skirtingus socialinius (pavyzdžiui, vadovaujančius) vaidmenis; skirtinguose segmentuose naudojami praktiškai vienodi socialinès integracijos modeliai, o darbo pasidalijimo lygmuo yra žemas ir dauguma darbų visi bendruomenès nariai atlieka kartu. Tai sąlygoja bendruomenès narių menkesnị individualumo ir didesnị bendruomeniškumo lygị, nes kiekvienas asmuo savo gebejjimais, žiniomis, igūdžiais santykinai nedaug skiriasi nuo kito asmens. Segmentuota visuomenė yra savotiškas šeimos ir politinès bendruomenès mišinys. Tai šeima, kurioje kiekvienas bendruomenès darys bendrauja su kitu kaip su giminaičiu (ir iš tikro dauguma jų yra kraujo giminės). Jų socialiniai santykiai su aplinka yra grịsti šeimos modeliu ir aprèpia kolektyvinę atsakomybę, kolektyvinị kerštą ir kolektyvini nekilnojamojo turto valdymą bei paveldejjimą. Vis dèlto tai nèra šeima tikrąja šio žodžio prasme. Tam, kad taptum bendruomenès nariu, kraujo giminystè su kitais bendruomenès nariais nèra privaloma sąlyga. Tokios visuomenès socialinę integraciją užtikrina ne kraujo giminystè, o visiems bendros vertybès, elgesio normos, ịsitikinimai. Kitos bendruomenès, pripažįstančios tas pačias vertybes, elgesio normas ir ịsitikinimus, segmentuotos visuomenès modelyje gali būti traktuojamos kaip giminès [12], juolab kad santuokos tarp skirtingų bendruomenių narių turèjo būti paplitęs reiškinys. Toks segmentuotos visuomenès apibrěžimas iš esmès atitinka Kalervo Obergo segmentuotos genties apibrèžimą, kuriame vienas svarbiausių akcentų yra bendruomenès narių giminystès ryšiai [45, 4765-480]. Giminystès ryšius, kaip vienus svarbiausių segmentuotoje visuomenejje, išryškina ir E. R. Service’as. Jo nuomone, paprastai šias visuomenes sudaro daugiau ar mažiau sèslūs žemdirbiai, gyvenantys kaimų gyvenvietėse, tarp kurių dar nèra dominuojančios gyvenvietės [52, 154-156]. Pagrindinis segmentuotos visuomenès uždavinys - užtikrinti efektyvų visiems bendruomenès nariams svarbių išteklių administravimą ir kartu bendruomenès išlikimą. Dẻl prasto dirvožemio ir menkos žemès ūkio dalies bendroje ūkio struktūroje Dubingių mikroregione dar pirmaisiais amžiais po Kr. gyventojų turèjo būti nedaug, atstumai tarp gyvenviečių dideli, socialinė diferenciacija turejjo būti labai menka, o socialinè segmentacija igyvendinama remiantis kitais, ne turto, kriterijais. Tokie kriterijai galejjo būti amžius ar lytis, kurie (ne vien kaip biologinès, bet ir kaip socialinès kategorijos) ryškūs ir vėlesnejje Rytų Lietuvos pilkapių 
kultūroje [32, 112-114]. Greta jų svarbiu kriterijumi galèjo būti individualūs gebejjimai (vartojant šiuolaikinius terminus - lyderystè, verslumas), taip pat fizinè jèga, greitis, kurie archeologijos tyrimo metodais nefiksuojami.

\section{SOCIALINĖS ORGANIZACIJOS RAIDA ANTRUOJU LAIKOTARPIU (II-IV, XI-XIII a.)}

Antruoju laikotarpiu pasikeitęs ekonominis gyvenimas sudarè sąlygas monogaminès šeimos kaip savarankiško ekonominio bei socialinio vieneto iškilimui (tam neprieštarauja laidosenos duomenys [32, 123]), padidino perteklinès (pardavimui skirtos) produkcijos kiekị ir sukūrè prielaidas individualiai (ne bendruomenès) privatinei žemès nuosavybei bei visuomenès socialinei diferenciacijai. Privatinè (šeimos) žemès nuosavybė LDK, kai kurių autorių nuomone, įvardijama kaip viduramžių civilizacinis skirtumas, ženklinęs skirtingą LDK valstiečių padėtị nuo Maskvos kunigaikštystei ir Rusijai būdingų valstietiškų bendruomenių žemévaldos [25, 286-289]. Tokios žemès nuosavybès atsiradimą pirmiausia lèmè vienos šeimos galimybės įdirbti „savo“ sklypą dvilaukès ariamosios žemdirbystės būdu. Visa žemè, kurią šeima „išsikovodavo“ iš gamtos (miško), tapdavo potencialia tos šeimos nuosavybe. Esant santykinai nedideliam gyventojų skaičiui ir dideliam „laisvos“ žemès plotui Lietuvoje antruoju laikotarpiu nesuveikè bendruomenès, kaip resursų panaudojimo reguliatoriaus siekiant bendros visų naudos, funkcija. Tai sudarè sąlygas nykti bendruomeninei žemèvaldai ir kurtis individualiai, šeimų žemès nuosavybei, o šeimai tapti pamatine korporacine gardele, pagrindiniu socialinio kapitalo kūrimo vienetu, su kitomis šeimomis bendraujančiu per giminyste grịstus asmeninius ryšius ir šiais ryšiais grịstas socialines interakcijas. Taigi ankstyvojoje viduramžių lietuvių (vèliau LDK) pagoniškoje visuomenejje, skirtingai nuo Vakarų Europos, nesant rašytine tradicija pagrịstos teisinès sistemos ir rašytiniais teisès aktais reglamentuotų korporacinių vienetų (ordinų, cechų, gildijų ir kt.), pagrindiniu korporaciniu socialiniu vienetu tampa neformalizuotais horizontaliais giminystès ryšiais susaistytų asmenų grupès (šeimos, giminès). Kai kurios šeimos / giminès ilgainiui igijo turtinị bei ekonominị pranašumą (įdirbo ir valdè didesnius žemès plotus nei kiti). Tokios giminès per „prièmimo i šeimą " tradiciją galejo pasitelkti kitus mažiau turtingus žmones šiam potencialui didinti. Nuo XII a. pab. - XIII a. pr. Lietuvoje įsitvirtinusi individuali nuosavybė vienos šeimos, kaip savarankiško vieneto, privati (nebendruomeninè) žemėvalda vẻlesniais laikais išskiriama kaip specifinis LDK ekonominès struktūros bruožas [11, 275-275]. Bajoras galejo disponuoti valda tik pritarus giminaičiams, o tèvoninès valdos negalejo virsti preke. XV a. pabaigoje atsiradus „trečdalio sampratai“, individualus bajoras galëjo laisvai, be giminaičių pritarimo, disponuoti tik $1 / 3$ savo valdų $[25,244]$.

Antruoju laikotarpiu greičiausiai dvilaukè žemdirbystė davė postūmi socialinei organizacijai susiformuoti, kurioje ne žemè pati savaime, o ją dirbantys žmonès yra vertybè. Tai padejjo pagrindus asmenine priklausomybe grịstiems santykiams formuotis. Tačiau darbas pats savaime nesukurdavo žemès nuosavybès. Žinoma, kad vikingų laikų skandinavų kultūroje tam buvo skirtos specialios apeigos, kurių pagrindinis elementas buvusi ugnis [16, 202-203]. Neturime duomenų apie baltų žemės nuosavybès įteisinimo apeigas pirmaisiais amžiais po $\mathrm{Kr}$., tačiau šiuo požiūriu galimos įdomios sąsajos tarp žemès nuosavybès ir mirusiųjų palaikų deginimo bei ankstyvųjų rašytinių šaltinių apie baltų pagonybę užuominos apie išskirtinę ugnies kulto reikšmę [70, 270-271, 316-317]. Remdamiesi palaidojimų medžiaga, bendro visuomenès turtingumo augimą ir išryškejjusią socialinę diferenciaciją romėniškuoju laikotarpiu pažymi praktiškai visi autoriai. Ypač šis procesas buvęs labai ryškus Vakarų Lietuvoje; čia III-IV a. atsirado ypač turtingi kapai bei padaugejo importinès 
kilmès dirbinių [22]. Tačiau socialinè diferenciacija pati savaime nepaaiškina, kaip turtinė nelygybė galèjo virsti politine nelygybe. Dvilauke sejjomaina grịsta ariamoji žemdirbyste iš principo sudarè sąlygas daliai bendruomenès narių tapti „profesionaliais“, bendruomenès natūrinėmis dovanomis išlaikomais vadovais. Tačiau kas skatino bendruomenę dovanomis išlaikyti vadovus, keisti nuo seno nusistovẻjusią tvarką? Bandydami atsakyti ị ši klausimą turètume ieškoti išorinių proceso priežasčių ir sustoti ties vadinamuoju tautų kraustymusi, kuris galejo tapti mutacinio pobūdžio sukrètimu. Esant nestabilumo laikotarpiui efektyviau hierarchiškai administruojama bendruomenė turejo daugiau galimybių išlikti. Dèl ekonominių ir mutacinių procesų iš esmès horizontali socialinė struktūra turẻjo keistis, grafiškai igydama netaisyklingo paraboloido formą. Viena vertus, mažosios šeimos tarpusavio ryšiai ir šeimos narių ryšiai su kitais bendruomenès nariais turẻjo hierarchizuotis šeimos vidiniams ryšiams stiprẻjant ir daliai asmeninių ryšių transformuojantis į giminès vidinius (tos pačios giminès šeima su šeima) arba giminyste nesusietų grupių ryšius. Kita vertus, bendruomenès viduje vykstant socialinès diferenciacijos procesams ir formuojantis vadystei dalis horizontalių asmeninių ryšių bendruomenès viduje šiuo laikotarpiu turèjo vertikalèti ir (ypač laikotarpio pabaigoje) trūkinèti, tai yra asmeniniai ryšiai ịgavo socialinès diferenciacijos pobūdį. Nepaisant visuomenès socialinės diferenciacijos, aukštesniųjų ir žemesniųjų socialinių sluoksnių bendravimas išlaike daugumą tiesioginių asmeninių ryšių ir tiesioginių, net labai individualių interakcijų. Tokio socialinio tinkliškumo pavyzdžiu galètų būti labai vèlyvas, žinomas net XVI-XVII a. (visiškai socialiai segmentuotos LDK visuomenès), bičiulystės reiškinys tarp valstiečių ir smulkiųjų bajorų [25, 293].

Kita dalis asmeninių ryšių (tarp to paties socialinio sluoksnio žmonių) bendruomenių viduje liko horizontalūs, kaip ir ankstesniu laikotarpiu. Tarp skirtingų bendruomenių ryšiai turèjo stiprèti (sudarydami pagrindą genčių formavimuisi), tačiau jų pobūdis keitèsi. Asmeniniai ryšiai tarp skirtingų bendruomenių ịvairių socialinių sluoksnių šiuo laikotarpiu turejo iš dalies nykti, tačiau jų vietoje turèjo rastis skirtingose bendruomenèse gyvenančių to paties socialinio lygmens asmenų asmeniniai arba grupių (šeimų / giminių) horizontalūs korporaciniai ryšiai. Šiuo laikotarpiu per karo žygius, vedybas, prekybos ryšius turèjo pradèti formuotis nuolatinių asmeninių ryšių tinklas su nutolusiais (kitos kultūros bendruomenių) nariais, tačiau šie ryšiai turèjo būti socialiai angažuoti, t. y. prieinami tik aukštesniojo socialinio statuso asmenims. Socialinès interakcijos bendruomenès viduje kito kartu su socialiniais ryšiais, tai yra dalis jų darèsi vertikalios, dalis liko horizontalios, formavosi ne tik asmeninès, bet ir grupių (šeimų, giminių) interakcijos. Savarankiška šeimų ekonominè veikla turejjo skatinti naujų ekonominių socialinių interakcijų (pvz., talkos, kuri ilgainiui virs lažu) atsiradimą. Socialinių interakcijų vertikalèjimo atveju jų nutrūkimas dèl turtinès hierarchijos buvo kur kas lètesnis nei dèl asmeninių ryšių. Net ir nutrūkus asmeniniams ryšiams tarp skirtingų socialinių sluoksnių žmonių, socialinės interakcijos galejo vykti išlaikant senąsias tradicijas ar siekiant bendrų tikslų, tačiau jų pobūdis turèjo keistis, prarasdamas natūralioms socialinèms interakcijoms būdingą specifiką (pavyzdžiui, savanoriškos dovanos bendruomenès vadui transformuojasi ị duoklę). Socialinès interakcijos tarp skirtingų bendruomenių turejo segmentuotis pagal socialinius sluoksnius. Dẻl stiprejjančios prekybos ir karo žygių silpnėjo bendruomenių "lokalus“ uždarumas, o socialinės interakcijos su kitų kultūrų bendruomenėmis prarado atsitiktinị (nereguliarų) pobūdị ir tapo reguliariais susitikimais iš anksto suderintose geografinèse erdvėse. Aptardami socialines interakcijas karo žygių kontekste turime pažymèti, kad užpuoliko ir besiginančiojo santykis nelaikomas socialine interakcija, karo žygiai skatino 
socialines interakcijas kitokiu, sąjungininkų paieškos, būdu. Asmeninių ryšių ir socialinių interakcijų specifika suformuoja antrajam laikotarpiui būdingą visuomenès tinklaveiką, kurios svarbiausi bendrieji požymiai buvo dalies asmeninių ryšių ir socialinių interakcijų vertikalëjimas, vertikaliųjų ryšių nykimas bei horizontaliųjų ryšių ir interakcijų tarp geografiškai nutolusių to paties socialinio lygmens grupių formavimasis. Bendruomenių homogeniškumas ir uždarumas silpnejjo priklausomai nuo jų socialinio sluoksnio. Aukštesniųjų socialinių sluoksnių atvirumas augo kur kas greičiau nei žemesniųjų socialinių sluoksnių. Bendruomenių socialinio kapitalo verčių kūrimas transformavosi pagal hierarchinį modelį, tai yra daugiausia socialinio kapitalo buvo sukuriama mažojoje šeimoje, šeimų kuriamas socialinis kapitalas sudarè vieno socialinio sluoksnio kuriamą kapitalą, o visos bendruomenès kuriamas socialinis kapitalas priklausẻ nuo skirtingų socialinių sluoksnių sąveikos. Bendruomenių išoriniai ryšiai turèjo kurti gerokai didesnę socialinio kapitalo dali nei pirmuoju laikotarpiu, ir tai turèjo ženkliai padidinti visuomenès evoliucijos tempą, mažinti (ypač aukštesniųjų socialinių sluoksnių) konservatyvumą, didinti (vėlgi ypač aukštesniųjų socialinių sluoksnių) perimamų inovacijų kiekị ir mažinti bendrą visuomenès atsparumą „mutacinio“ pobūdžio situacijoms. Socialinio kapitalo kūrimo mechanizmas iš dalies galètų paaiškinti ir trilaukès sẻjomainos atsiradimą antrojo laikotarpio pabaigoje - šio laikotarpio pabaigos visuomenè buvusi kur kas atviresnè inovacijoms nei laikotarpio pradžioje.

Visuomenès tinklaveika ir socialinis kapitalas suformavo antrajam laikotarpiui būdingą socialinę organizacijos formą - vadystę. Mokslinejje literatūroje vadystè yra apibrèžiama kaip socialinès ir politinès organizacijos forma, kai politinė valdžia ir ekonominè galia bendruomeneje yra sukoncentruotos ir igyvendinamos vieno religinio, ekonominio ar karinio lyderio - asmens ar asmenų grupès. Paprastai ši valdžia nebuvo paveldima, nebent išskirtiniais atvejais. Remiantis Rytų Lietuvos pilkapių kultūros laidosenos medžiaga, „...statuso paveldimumo požymius suaugusiųjų kapuose ịžvelgti yra sudètinga. Suaugusio asmens laidojimo būdą igyta ir igimta padètis galëjo lemti vienodai. Netiesioginiu paveldimos padèties egzistavimo indikatoriumi galima laikyti pavienius išskirtinai turtingus pagyvenusių vyrų ir neturtingiausius jaunų suaugusiųjų kapus. Jie rodo, kad statusas ne visuomet buvo susijęs su amžiumi ir nuo jo priklausančiomis individualiomis savybemis. Galbūt visuomenèje funkcionavusios socialinès normos kiek kitaip galiojo aukščiausio ir žemiausio sluoksnio atstovams. Tikètina, kad aukščiausią statusą turintys asmenys sugebėdavo ji išlaikyti (ir perduoti palikuonims) netgi vyresniame amžiuje. Padèties paveldimumo požymiu galima laikyti ir turtingus moterų kapus - t. y. aukšto statuso vyrų gebejjimą perteikti savo socialinę padètị šeimos nariams..." $[32,118-119]$. Vis dèlto kai kurių autorių teiginys apie socialinių klasių (socialinè struktūra užtikrina neatitikimą tarp individo galimybių užimti tam tikrą padètị visuomenèje ir realiai užimamos padèties) egzistavimą antruoju laikotarpiu yra abejotinas. Lietuviška vadystės socialinè struktūra buvo atviresnè ir lankstesnè nei to meto Vakarų Europoje. Apie socialinès sistemos atvirumą (galimybę migruoti tarp socialinių sluoksnių) žinoma iš gerokai vẻlesnių laikų (XVXVI a.) LDK dokumentų [25, 294-296]. Antrojo laikotarpio vadystės pagrindinès funkcijos greičiausiai buvo resursų perskirstymas, teisingumo vykdymas bei bendruomenès sutelktis resursams išsaugoti ir didinti (gynybai / plèšikavimui). Dėl didelių atstumų nuo svarbiausių antrojo laikotarpio centrų ir dèl X a. prasidejjusios kultūrinès izoliacijos besiformuojančios LDK visuomenè atsidūrè savotiškoje „saloje“. Valstybès kūrimosi išvakarèse socialinès organizacijos požiūriu būsimoji Lituania propria erdvè turèjo būti panašesnè ị geografinèje 
saloje buvusią anglosaksų erdvę iki 1066 m. Hastingso mūšio nei ị kontinentinès Europos erdvę: „...grèsmès atveju visi [laisvieji] vyrai [nepriklausomai nuo jų socialinès padèties] turèjo eiti kariauti $\langle\ldots\rangle$ ir kovojo jie pėsčiomis $\langle\ldots\rangle$ anglosaksai neturejo kavalerijos <...> taigi susidūrimas prie Hastingso buvo ne vien dviejų kariuomenių, bet ir dviejų skirtingų kariavimo taktikų susidūrimas $<\ldots>$ senas anglosaksų kariavimo būdas neatlaikè susidūrimo su kontinentine kavalerija..." [78, 574].

Bandant identifikuoti antrojo laikotarpio visuomenès socialinę struktūrą yra svarbi šaltinių interpretavimo problema. Bene nuo XIX a. įsigalèjusi nuomonè apie tiesioginę pilkapio dydžio ir jame palaidoto asmens turtingumo priklausomybę [32, 52-55] yra koreguotina. Hipotetiniu lygmeniu galime kalbèti apie pilkapio dydžio ir jame palaidoto asmens (ar asmenų) socialinio statuso koreliaciją. Socialinio kapitalo požiūriu socialinị statusą lemiančių veiksnių grupès redukavimas iki vieno veiksnio - asmens turtingumo - būtų per daug didelis tikrovès supaprastinimas, pavojingas objektyviam praeities visuomenių supratimui. Rytų Lietuvos pilkapių kultūros atveju situaciją sunkina prielaida, kad monumentaliuose statiniuose - pilkapiuose galejo būti laidojamas tik socialinis elitas (individualizuoti kapai), o kiti bendruomenès nariai galèjo būti laidojami bendruose „kapų laukuose“. Galbūt dèl šios priežasties „...Rytų Lietuvos pilkapiuose ryškių ir aiškiai apibrèžiamų laidojimo būdo skirtumų, kuriuos būtų galima sieti su konkrečiomis socialinèmis klasèmis, nepastebima...." $[32,130]$. Prisilaikydami prielaidos, kad pilkapiuose laidoti tik aukštesnio socialinio statuso asmenys, šiuose kapuose socialinių skirtumų galètume ieškoti pasitelkę skirtingus radinių kompleksus ar skirtingas radinių galimas socialines ir ekonomines vertes (9).

Teritoriniu požiūriu vadystė buvo natūraliai susiformavęs autonominis politinis ir ekonominis vienetas, apimantis kelis kaimus / bendruomenes (iš jų vienas kaimas pripažįstamas dominuojančiu centru), valdomus vieno asmens ar asmenų grupès [7, 53-55; 45, 478-480]. Savo teritorine aprèptimi Dubingių mikroregione vadystės turètų daugiau ar mažiau atitikti teritorines archeologijos objektų grupes [29]. Vadysčių centrų klausimas paprastai sprendžiamas sutapatinant juos su žinomais piliakalniais, ir tik gilesnè klausimo analizė leistų kalbėti apie kitokias centrų išskyrimo tendencijas. Laikydamiesi atviros vadystès socialinès organizacijos idejjos (kad žmogaus socialinị statusą bent iš dalies lèmė jo gebejjimai, o vado valdžia nebuvo paveldima) galètume kelti prielaidą, kad centras buvo migruojantis: vadystès centru tapdavo socialinio ir politinio lyderio sodyba (nebūtinai pilis, gal kaimas, atvira sodyba ar dvaras), o vadui pasikeitus, centras galejo persikelti $\mathfrak{i}$ naujojo vado sodybą (10). Šiuo požiūriu įdomi Jungtinèje Karalystèje taikoma gyvenviečių klasifikavimo schema [40], pagal kurią pilis yra vieno asmens (vienos šeimos) rezidencija, o gyvenviete skirta keletui ar keliolikai šeimų. Toks nuosavybe grịstas kriterijus gali būti sėkmingai taikomas ir skiriant kaimą nuo dvaro. Vadystès centro ir „periferijos“ santykiai buvo grindžiami asmeniniais vado ir „jo žmonių“ ryšiais bei per šiuos ryšius atsirandančia

(9) Pavyzdžiui, galime daryti prielaidą, kad kalavijo vertẻ buvusi didesnè nei ietigalio. Radinių santykines vertes galima bandyti nustatyti ir remiantis L. Jørgenseno [20] bei N. Ringstedo [54] metodikomis. Socialinès organizacijos ir pasaulèžiūros kaitą taip pat galima būtų tyrinèti analizuojant kalavijo, kaip aukščiausiojo socialinio sluoksnio ginklo, radinių kiekybinị pasiskirstymą Lietuvos archeologijos medžiagoje. Intensyvejjant kovoms su Vokiečių ordinu, XIV-XV a. kalavijų turèjo būti naudojama daugiau, tačiau šio laikotarpio kalavijų tèra tik pavieniai radiniai.

(10) Tokių vietovių identifikavimui galètume panaudoti vietovardžių etimologijos duomenis. Centrinès vietovès pavadinimas turètų būti asmenvardinès (greičiausiai sudurtinis lietuviškas asmenvardis) kilmès. Dubingių regione tokio vietovardžio pavyzdžiu galètų būti Jagomanto ežeras. 
teritorijos „nuosavybe“. Taigi žemės nuosavybė antruoju laikotarpiu buvo igyvendinama per tiesioginès nuosavybės (tèvoninè, privati šeimos valda) ir asmeninius (besiformuojanti baudžiava) santykius. Vadui ir jo šeimai priklausẻ jų pačių nuosava ir „jo žmonių“ žemè. Tokios valdos tapo svarbia ekonominès ir politinès galios akumuliavimo priemone, kai sava žemé, turimų žmonių kiekis ir jų dirbama žemė tapo vienu svarbiausių vado išteklių. Asmeniniais, korporacinio pobūdžio asmeniniais ir šeimų ryšiais susijusių asmenų žemès valdos nors ir nebuvo tiesioginè vado nuosavybè, tačiau taip pat sudarè ir stiprino jo politinę ir ekonominę galią (stiprus tas, kuris turi daug draugų).

Vadystès laikotarpio socialinès struktūros kaitą Rytų Lietuvoje rodo pilkapių kultūros atsiradimas. Ši kultūra formavosi vèlyvosios brūkšniuotosios keramikos kultūros pagrindu, veikiama gretimų rytų baltų (Bancerovo kultūros) ir vakarų baltų (Sūdūvių kultūros). Kaip rodo pats kultūros pavadinimas, laidojimas monumentaliuose statiniuose - pilkapiuose buvo vienas svarbių Rytų Lietuvos pilkapių kultūros skiriamųjų elementų. Literatūroje îsigalejusi iš esmès teisinga nuomonè apie mūrinę statybą kaip civilizacijos požymị [4, 80-83] gali būti išplèsta ịtraukiant kitokius monumentaliuosius statinius. Pilkapių pylimo papročio atsiradimas gali būti vertinamas kaip vadystei būdingos monumentaliosios statybos [7, 53] faktas ir naujos socialinès organizacijos požymis (11). $2012 \mathrm{~m}$. tirtame Jutonių pilkapyno pilkapyje buvo panaudota $120,86 \mathrm{~m}^{3}$ grunto [62]. Remdamiesi suaugusio žmogaus per dieną atliekamo darbo skaičiavimais $[46,1086]$ ir tiketinais pilkapynus supylusios bendruomenès dydžiais bei struktūra [32, 156], galime teigti, kad vidurinio geležies amžiaus žmonèms supilant pilkapius reikèjo įdèti labai daug darbo ir pastangų. Minètam Jutonių pilkapiui supilti 6 suaugusieji turèjo dirbti nuo ryto iki vakaro apie 20 dienų ir tik tokiu atveju, jei sampilui buvo imamas netoliese buvęs gruntas. Tokiems darbams yra būtinas centralizuotas vadovavimas ar (ir) administracinès struktūros. Platesniame kultūriniame kontekste pilkapių kultūros ir kūnų deginimo papročio išplitimą antrojo laikotarpio Rytų Lietuvoje galime traktuoti kaip esminị pasaulèžiūros pasikeitimą, kuri galejo lemti išorès poveikio ir / ar bendruomenès socialinès organizacijos kaita. III-IV a. Rytų Lietuvos archeologijos medžiaga nerodo tokio masto išorinès migracijos, kuri leistų teigti apie „mutacinio“ pobūdžio visuomenès sukrètimus, panašius ị totalią teritorijos okupaciją, ịvykdytą iš esmès kitos kultūros žmonių (nepripažįstančių griautinio palaidojimo po žeme), kurie primetė savo papročius autochtonams. Tokio esminio papročių pasikeitimo priežasties turètume ieškoti tų laikų visuomenès viduje - tai galètų būti turtinès diferenciacijos atsiradimas, socialinès organizacijos kaita ir vadystès formavimasis. Viena vertus, pasaulèžiūros kaita turèjo būti susijusi su poreikiu bendruomenès nariams logiškai paaiškinti naujus ekonominius ir socialinius reiškinius (privatinę žemès nuosavybę, socialinę diferenciaciją ir pan.), kita vertus - sietina su vieno socialinio segmento (vadas ir asmeniniais ryšiais su juo susiję asmenys) praktikuoto dangaus dievų kulto stiprèjimu kitų dievybių atžvilgiu. Kaip rodo archeologijos duomenys, pilkapių pylimo paprotys atsirado anksčiau nei kūnų deginimas [77, 244-247]. Pasikeitusią kapo „architektūrą“ galima sieti su panašiais bendrakultūriniais procesais, kai ị dangaus dievybes orientuotos kultūros savo

(11) Pilkapio kaip monumentaliojo objekto traktavimas įdomus ir kitokiu aspektu. Kultūroje pastebèta, kad monumentalieji statiniai laikui bègant paprastèdavo (būdavo sudètingesni konkrečios kultūros pradžios laikotarpiu nei pabaigoje). Panašių tendencijų galime atsekti ir pilkapių atveju, kai, pavyzdžiui: „....ankstyvuoju laikotarpiu dauguma atvejų laidojant vaikus buvo pilamas naujas pilkapis, tuo tarpu vèlyvajame geležies amžiuje absoliuti dauguma vaikų kapų buvo ịkasami ị ankstesnius sampilus..." $[32,72]$. 
papročiais „stiebiasi ị dangų“ ir, užuot grąžinusios savo mirusiuosius ị Motinos Žemès įsčias, tiesia jiems deginamosios aukos (dūmai kyla ị dangų) ir piramidès ar pilkapio formos kelią aukštyn. Kita svarbi religinių papročių kaitos priežastis galejjusi būti antruoju laikotarpiu padidèjęs visuomenès atvirumas ir skirtingų kultūrinių bendruomenių ryšiai. Kitai kultūrai priskiriamų asmenų („svetimųjų“) net ir laikinas atsiradimas sukelia potencialią grèsmę homogeniškai bendruomenei, kurios nariai pažinojo vieni kitus nuo vaikystès, ir šios žinios apie kitą asmenị buvo vieno kertinių socialinio kapitalo akmenų - pasitikejjimo - pagrindas. Šiuo požiūriu „iš kažkur“ atsiradę „svetimieji“ turejjo būti įtartini ir pasitikejimo jais lygmuo - menkesnis. Tai kèlè aiškią grèsmę socialinio kapitalo kūrimui bendruomenèje ir bendruomenès nariams reikejjo naujų socialinių „klijų“, kurie ne tik padidintų pasitikèjimą kraujo giminyste ir „pažintimi nuo vaikystès“ nesusijusiais „svetimaisiais“, bet ir išlaikytų ryšius tarp besidiferencijuojančių skirtingų socialinių sluoksnių, neleisdami visuomenei „subyrèti“ turtiniu pagrindu. Moksliniai tyrimai pripažįsta, kad vienas stipriausių tokių socialinių „klijų“ yra religija, kai bendras dalyvavimas tose pačiose apeigose trina barjerus tarp „savųjų“ ir „svetimųjų“, tarp turtingųjų ir beturčių, didindamas tarpusavio pasitikèjimą [36, 14-17]. Galime teigti, kad formuojantis vadystei senoji pasaulèžiūra susidūrè su esminiais iššūkiais ir turèjo centralizuotis tapdama geresniais socialiniais „klijais.“ Naujų, labiau centralizuotų, religinių pažiūrų valdantysis elitas atkūrè ir padidino mąžtančias socialinio kapitalo vertes bei sukūrè sąlygas didesnès nei mikroregiono erdvès centralizacijai (valstybei) atsirasti. Dubingių mikroregione bandydami rasti atitikmenu vadystei būdingam bendram teritoriniam ceremonijų centrui [7, 89] turètume atkreipti dèmesị ị Alkos vietovę, ịsikūrusią patogioje perejoje per ilgą ir sunkiai ịveikiamą Dubingių ežerą [66, 193-194].

Nederlingose Rytų Lietuvos žemėse antrojo laikotarpio socialinės organizacijos procesai galèjo turèti dar vieną specifinị požymị, svarbų tolesniam valstybės formavimuisi. Galime daryti prielaidą, kad nederlingose žemèse gyvenusios bendruomenès patyrè didesnị spaudimą verstis kitais, ne žemdirbiškais, verslais, o šių žemių valdantysis elitas karo žygius laikè priimtinesne turto kaupimo priemone nei pakankamai kuklias neturtingų jiems pavaldžių žmonių duokles ar prekybą menkais žemės ūkio sukuriamais ištekliais. Galime daryti prielaidą, kad prastesnèse (mažiau derlingose) žemėse gyventojų skaičiaus augimas labiau skatino organizuoti karo žygius nei toks pat gyventojų skaičiaus augimas derlingose žemėse. Tokia ūkio struktūra turèjo kurti didesnę socialinę atskirtị nei gerų dirvožemių regionuose, nes karo žygiuose nedalyvaujantys prastų žemių bendruomenès nariai turèjo kur kas mažesnius išteklius kurti pridedamąją žemdirbystès ir gyvulininkystès vertę nei gerų žemių ūkininkai. Karo žygiuose aktyviai dalyvaujantys bendruomenès nariai, pasisavindami kitur sukurtas (savo ir sau priklausančių žmonių neuždirbtas) pridètines vertes, turèjo būti santykinai turtingesni nei derlingų žemių vadai. Panašūs procesai fiksuoti Suomijoje atliktuose tyrimuose: pastebèta tendencija, kad mažiau žemdirbystei tinkamuose regionuose skirtingų visuomenès grupių socialinė atskirtis XVI-XVII a. buvusi didesnè nei žemdirbystei palankiuose regionuose [42, 338-341]. Intensyvūs karo žygiai didino tų laikų bendruomenių atvirumą, plètė asmeninius ryšius ir socialines interakcijas už bendruomenių ribų (su kitų kultūrų bendruomenemis) bei atliko lemiamą vaidmenị kuriant inovacijų kapitalą (nederlingose žemėse inovacijų poreikis didesnis nei derlingose, nes ekstensyvi plètra anksčiau pasiekia galimybių ribą). Mokslinèje literatūroje pastebima, kad aukščiausio socialinio sluoksnio ir mobiliausio asmens - valdovo - dvarai buvo vietiniai inovacijų centrai $[11,124-125]$. Valdančiojo elito „priverstinis“ mobilumas ir 
atviresnè visuomenė, greičiausiai, yra viena priežasčių, kodèl būsimosios Lietuvos valstybès branduolys iškilo nederlingoje Rytų Lietuvos geografinèje erdvejje.

\section{SOCIALINĖS ORGANIZACIJOS RAIDA TREČIUOJU LAIKOTARPIU (XI-XIII, XVI a.)}

Trečiuoju laikotarpiu toliau vyko turtinès diferenciacijos ir ja grịstos socialinès diferenciacijos procesai, formavosi LDK viduramžių feodalinè visuomenè. Tačiau, skirtingai nuo feodalizacijos procesų krikščioniškoje Vakarų Europoje, besiformuojančioje LDK valstybės erdveje nesusidarẻ aiškiomis, juridiškai apibrěžtomis korporacinèmis grupėmis (pirklių gildijos, amatininkų cechai, miestų komunos, vienuolių ordinai ir pan.) grịsta socialinè struktūra ir pamatiniu korporaciniu vienetu tapo iš antrojo laikotarpio "paveldèta“ šeima / giminè. Korporaciniu požiūriu šeimoje patriarchalinio pobūdžio „vyresniojo ir jaunesniojo“, „tèvo ir sūnaus“, „brolių ir seserų“ tarpusavio santykis yra lengviausiai atpažįstamas, o tèvo, motinos ir vaikų grupe (mažoji šeima) yra aiškiausia giminystès išraiška [25, 241-243]. Greta mažosios šeimos yra išlaikomas platesnis giminystès laukas (iš pradžių kraujo, vèliau juridiniais saitais susieta giminè), kurio korporaciniams ryšiams ir „administravimui“ pritaikomi iš šeimos pažizstami modeliai. Galime teigti, kad LDK viduramžių socialinè specifika buvo ta, kad pagal patriarchalinès šeimos modelị buvo konstruojama absoliuti dauguma visuomenès struktūrų. Toks santykis ryškus Gedimino 1324 m. pareiškime popiežiaus legatams, kur Lietuvos valdovas išdėsto savo hierarchijos supratimą: „...paskui jis [Gediminas] tvirtino, jog apaštališkąji viešpatị jis norịs laikyti tèvu, kaip rašè, nes „jis yra vyresnis už mane; ir kitus tokius laikysiu tèvais, ir poną arkivyskupą panašiai laikysiu tėvu, nes jis vyresnis už mane; o tuos, savo vienmečius, laikysiu broliais; jaunesnius už save - sūnumis“..." [70, 390]. Patriarchalinès šeimos modelis ryškus ir viduramžių LDK žemévaldoje. Valdovas ar bajoras iš esmès valde daugiau žmones, o ne preciziškai apibrèžtą teritoriją. Tarp kilmingųų toks asmeninis pavaldumas buvo apibrěžiamas specifiniais, patriarchalinei šeimai būdingesniais „tèvo ir sūnaus“ ryšiais grịstais LDK besiformuojančiais senjoro ir vasalo santykiais [11, 251-255], kurie ne tik LDK nesuformavo Vakarų Europai būdingos feodalinès piramidès [25, 246], bet ir stabdè Vakarų Europos tradicijoje žinomų uždarų korporacinių vienetų bei socialinių klasių formavimąsi. Nekilmingieji tarpusavyje ir su aukštesniaisiais socialiniais sluoksniais labiau buvo susieti „tèvo ir sūnaus“ ryšiu nei miestų privilegijomis ir formalizuota baudžiavine sistema. Žmogaus kaip resurso ir asmeniniais ryšiais grịstos žemės nuosavybės samprata yra labai ryški viduramžių LDK karų aprašymuose, kai grobikiško žygio metu buvo stengiamasi nužudyti arba, jei tai pavyksta, išsivaryti priešui priklausančius žmones ị savo valdas. Galime manyti, kad XIV-XV a. „atkirtis“ reiškė ne tiek ịsiveržusios priešo kariuomenès sustabdymą ar sunaikinimą paties įsiveržimo metu, kiek plešikišką žygi i t priešo teritoriją ar kitas žemes ateityje, siekiant atkurti pirmojo žygio metu sunaikintus resursus. Juk paradoksalu, kad, pavyzdžiui, $1373 \mathrm{~m}$. ir $1374 \mathrm{~m}$. Livonijos ordino kariuomenė keletą dienų plèšikauja vos vienos dienos kelionès atstumu nuo Vilniaus, tačiau nesulaukia jokių LDK kariuomenès atsakomųjų veiksmų. Toks personalizuotas žmogaus ir žemės santykis užfiksuotas ir XVXVI a. dokumentuose, kai neleista perleisti kitam savininkui valstiečio be jo žemės [25, 292]. Dèl patriarchalinio modelio poveikio lietuvių ir kitų baltų genčių kilmingieji paprastai vaizduojami šeimos ir draugu apsuptyje [11, 249-251]. 1401 m. Vilniaus ir Radomo sutartyje Lietuvos bajorai dalyvauja kartu su savo giminaičiais [25, 241]. Pažymėtina, kad šeima grịstas korporatyvumas buvo būdingas ir platesniam Rytų Europos regionui (pvz., Lenkijai), ir tai ypač išryškejjo, kai po Lietuvos krikšto katalikiškoji LDK bajorija 1413 m. 
Horodlejje igijo herbus ir vèliau tuos herbus perdavė LDK stačiatikių bajorijai ar kai XV a. bajorai ị savo giminę prièmè ūkiškai stipresnius aplinkinių žemių nekilmingus gyventojus [25, 241-242]. XIV-XVIII a. LDK ir Lenkijoje nobilitacijos procesas visiškai skyrèsi nuo panašių procesų vokiškoje Šventosios Romos imperijos erdvejje ir iš esmès buvo grịstas "prièmimu ị šeimą“, o ne abstrakčiu naujo herbo ar titulo suteikimu „pakeliant ị riterius“. Patriarchalinès šeimos modelio taikymą LDK skatino ir tai, kad dèl besiformuojančios LDK politinio elito pagoniškos pasaulèžiūros buvo sukurta religiniu požiūriu tolerantiška aplinka idejų mainams, o pagoniška religija nebuvo tokiu korporatyvumo formų katalizatoriumi, kokia buvo katalikybė. Pagoniškos pasaulèžiūros terpèje vykusi rytų ir vakarų krikščioniškų civilizacijų sąveika formavo specifini LDK socialinị kraštovaizdị. LDK būdingas šeimos / giminès modelis nuo krikščioniškojo skyrèsi ne tik teisinio reglamentavimo nebuvimu, bet ir santykiu su laiko struktūromis. Dèl pagonybei būdingos ciklinès (ne linijinès) laiko sampratos „....ankstyvųjų laikų giminės ne tik neturèjo paveldimų vardų, bet ir ilgesnès giminès tradicijos, genealoginio pasakojimo..." $[25,242-$ 243]. Ciklinis laikas skatino horizontalųjị, o ne linijinị laike ištęstą giminystès suvokimą, ne tiek prisiminimus apie praeiti ar ateities projektavimą (strateginị planavimą), kiek horizontalius ir toli siekiančius tos pačios kartos giminaičių ryšius per moterišką ir vyrišką linijas. Pagoniškoje visuomenėje protèviai turèjo būti gerbiami neindividualizuoti, kaip abstraktūs „tiesiog protèviai“, o pirmieji linijinio pobūdžio genealoginiai pasakojimai LDK atsirado tik su Jogailos ir Vytauto krikštu (12). Net Mindaugo karūnos istorija LDK buvo pamiršta ir išsaugota tik Vokiečių ordino raštuose [10]. Trilauke žemdirbystė socialiniam kraštovaizdžiui suteikẻ tik LDK būdingų ekonominių bruožų. Antrojo laikotarpio pabaigoje Rytų Lietuvoje išryškejusi socialinė diferenciacija tarp tų, kurie gyveno iš karo žygių, ir tų, kurie pragyveno vien iš žemdirbystės, turejjo igyti ekstremalų pobūdį. Mažinant atskirtị svarbų vaidmenį atliko trilaukẻ sejjomaina, kuri dẻl efektyvesnio ūkininkavimo bei naujų žemès ūkio kultūrų ir technologijų sukūrè gerokai didesnes pridedamąsias vertes nei dvilaukè sẻjomaina. Tai sąlygojo pakankamai stipraus kaimiško žemdirbių „vidurinio sluoksnio" susiformavimą, kuris gravitavo socialinio paraboloido viršūnès link ir vèliau, XV-XVII a., sudarė vadinamųjų žiemionių (vẻliau paniekinamai vadintą plikbajorių) socialinị sluoksnị. Galime spèti, kad trečiuoju laikotarpiu dalis valstiečių trilaukès sejjomainos dèka galèjo prasigyventi iki tokio socialinio lygmens, kuris išlaikè glaudžius asmeninius ryšius su valdančiuoju elitu ir kartu su krikštu buvo ịteisintas kaip bajorija, nors savarankiškai dirbanti žemę, bet periodiškai dalyvaujanti karo žygiuose. Greičiausiai dèl to XIII a. pradžioje Lietuvos diduomenè buvusi atviresnè ir socialiai labiau diferencijuota nei Prūsijos ar Livonijos teritorijose [11, 251-255]. Tokiomis sąlygomis trilaukès žemdirbystès veikiamas šeimos / giminès modelis trečiuoju laikotarpiu turèjo transformuotis iš grynai biologinès (kraujo giminyste paremtos) ị daugiau socialinę kategoriją, pagal kurią nemaža dalis šeimos narių buvo priimta adopcijos būdu. Toks „vidurinio sluoksnio“ formavimosi procesas paaiškintų iš vèlesnių laikų (XVI-XVIII a.) žinomą LDK specifiką - santykinai dideli (iki 10 proc.) bajorų procentą visuomenèje $[25,182]$.

(12) Istorinio laiko suvokimui XIV a. įdomus J. Długoszo užrašytas faktas, kai žemaičiu krikšto metu vienas vietinis žmogus, bandydamas paneigti Mikalojaus Venžiko pasakojimą apie Pasaulio sutverimą ir Adomo nuopolį, argumentavo, esą ,... kunigas, skelbdamas, kad šis pasaulis sukurtas, meluoja, juk jei žmogus neilgaamžis, tai kaip jis gali liudyti atsimenąs pasaulio sukūrimą? Tarp mūsų yra žmonių daug vyresnių, yra ir šimtą metų pranokusių, bet jie neprisimena to sukūrimo; žino tik, kad už tų kalvų ir upių visada švietè saulè, mėnulis ir žvaigždès." Pasak šio žmogaus, neįmanoma žinoti apie praeities ívykius, kurie atsitiko iki tavo gimimo. 
Šiame bendrame visuomenès raidos kontekste bendruomenès viduje svarbiausi turèjo būti grupių (šeimų) ir asmeniniai horizontalūs ryšiai. Dẻl pagoniškos pasaulèžiūros tolerancijos ir besiformuojančios valstybès daugiakultūriškumo horizontalūs ryšiai (ypač aukštesniųjų socialinių sluoksnių) turèjo būti grindžiami daugiau politiniais ir ekonominiais nei kultūriniais ar religiniais interesais. Bendruomenès viduje vykstanti socialinė diferenciacija turejjo silpniau pažeisti pagal turtingumą skirtingu grupių vertikalius ryšius ir jie, net formuojantis valstybei, turẻjo išlikti stipresni nei luominejje Vakarų Europos visuomenèje ar bizantiniu despotizmu grịstoje rytų krikščioniškoje visuomenejje. Iš valstiečių iškilusių ir savo turtingumu bei gyvenimo būdu nuo valstiečių menkai besiskyrusių žiemionių sluoksnis kartu su karo tarnais, raitininkais, „geraisiais žmonėmis“ buvo tarsi buferinė asmeninių ir šeimų ryšių zona tarp aukščiausios diduomenès ir valstiečių.

Skirtingų bendruomenių tarpusavio ir asmeniniai ryšiai su kitų kultūrų bendruomenèmis šiuo laikotarpiu turẻjo toliau stiprèti. Šiuo požiūriu svarbų vaidmenị atliko daugiataučių miestų kaip kultūrinès gravitacijos centrų radimasis bei LDK diduomenès suaktyvėję kontaktai su Vakarų Europos diduomene bei rusėnų kunigaikščiais. Dubingių mikroregionui ypač svarbi buvusi vos vienos dienos kelionės atstumu esančio Vilniaus „gravitacinè trauka" ir tai, kad aplink nebuvo jokių kitų stambesnių miesto pobūdžio gyvenamụjų vietovių, galinčių konkuruoti su Vilniumi.

Socialinès interakcijos bendruomenès viduje turejo išlikti panašios kaip ir antruoju laikotarpiu. Trečiuoju laikotarpiu daugiausia pastebimas socialinių interakcijų tarp skirtingų bendruomenių intensyvejjimas ir valdančiojo elito "globalių“ socialinių interakcijų sustiprejjimas. Socialinès interakcijos bendruomenès viduje galèjo igauti skirtingą pobūdị tik tais atvejais, kai dèl socialinès diferenciacijos nutrūkdavo tiesioginiai asmeniniai ryšiai ir formuodavosi „feodalo ir baudžiauninko“ santykiai: feodalui baudžiauninkai prarasdavo asmeninius bruožus ir tapdavo statistiniais ekonominiais vienetais - tarnybomis, dūmais, žmonėmis ir pan. Tokios kaitos požymių galime rasti XV-XVI a. rašytiniuose dokumentuose, kai vienu atveju, kalbant apie pavaldžius žmones, vartojami asmenvardžiai, pavyzdžiui (apie 1446 m.), „...tarnybą ir tuščią žemę, kurią prieš tai laikė Milius..., Dubingiuose gavo kažkoks Petrašas...“, o kitais atvejais tai yra tik abstraktūs asmenys: „...1482 m. Mikalojus Radvila Žemaitkiemio bažnyčiai dovanojo 8 žmones.... [51, 25-39]. Tokia situacija buvo įmanoma tik didžiausiose latifundinio pobūdžio valdose ir tik tarp aukščiausių ir žemiausių socialinių sluoksnių žmonių. Tiesioginiams asmeniniams ryšiams nutrūkus socialinès interakcijos buvo užtikrinamos per tarpininkus, kurie buvo susiję asmeniniais ryšiais tiek su vieno, tiek su kito socialinio sluoksnio žmonėmis. Tokiais socialinių interakcijų tarpininkais galejo būti jau minèti žiemionys ar valdą prižiūrintys pareigūnai (tijūnai, vietininkai ir pan.). Po LDK krikšto, plečiantis parapijų tinklui, asmeninių ryšių ir socialinių interakcijų erdvejje atsirado dar vienas veikèjas - katalikų bažnyčia (kaip korporacija) ir dvasininkas kaip asmuo. Kaimo vietovèse dvasininkas taip pat galejo užimti tarpininko poziciją skirtingų socialinių sluoksnių žmonių socialinėse interakcijose.

Pasikeitusi globalių asmeninių ryšių pobūdị rodo tai, kad šiuo laikotarpiu lietuviški asmenvardžiai atsiranda rusėniškuose ir lotyniškuose rašytiniuose šaltiniuose. Tai reikštų, kad besiformuojančios LDK valdantysis elitas kaimynų suvokiamas jau ne kaip abstraktūs „barbarai“, bet kaip konkretūs, personalizuoti veikèjai. Šiuo požiūriu kaip pripažinimo „savais“ ženklai yra svarbūs sẻkmingos Mindaugo ir nesèkmingos Vytauto karūnacijos faktai, taip pat Jogailos pakvietimas užimti Lenkijos karaliaus sostą. Asmeniniams globaliems ryšiams labiausiai trukdẻ LDK aukštųjų socialinių sluoksnių pagonybė, trikdžiusi 
krikščioniškuosius valdovus. Todèl intensyvesni globalūs asmeniniai ryšiai vyko tik krikšto kontekste, o realiai buvo "aktyvuojami“ tik po krikšto Lietuvos didžiojo kunigaikščio Vytauto laikais. Nepriklausomai nuo Lietuvos krikšto sąlygoto globalių asmeninių ryšių suaktyvejjimo šiuo požiūriu pirmasis monarchas, tapęs „visiškai savu“ Vakarų Europos valdančiajam elitui, buvo tik Žygimantas Senasis, pirmasis LDK valdovas, priimtas ị elitinị „Aukso vilnos“ ordiną.

Trečiuoju laikotarpiu ypač suintensyvejo socialinės interakcijos tarp skirtingų kultūrų bendruomenių. Viena vertus, susikūrus valstybei ir jai išplètus teritorijas rytų kryptimi, LDK natūraliai tapo daugiakultūre valstybe, kita vertus, miestų kūrimasis ir monarchų imigracinès politikos skatinimas (Gedimino laiškai, Vytauto atkeldinti karaimai ir totoriai) dar labiau mažino bendruomenių uždarumą, didino heterogeniškumą ir skatino visuomenès daugiakultūriškumą, tarpkultūrinių socialinių interakcijų poreikị ir galimybes. Dubingių mikroregione bendruomenių atvirumą skatino ir mutacinio pobūdžio sukrètimai. Po XIV a. Livonijos ordino žygių išžudytų gyventojų vietą turèjo užimti iš kitų regionų perkelti gyventojai. Greičiausiai tokių kultūrinę ịvairovę didinančios vidinès kolonizacijos pėdsakų galime rasti vietovardžiuose Gudeikiai, Žemaitèliai, Mozūriškès, kuršiams būdingos (kaip teigiama kalbiniuose tyrimuose) -ing- priesagos vartosenoje (plg. Dubingiai). Kartu gyventojų kaita ir Dubingių mikroregiono, kaip kolonizuojamos erdvès, statusas XIV a. pab. skatino kiek specifinę mikroregiono socialinę raidą. Moksliniai tyrimai rodo, kad kolonizuojamų regionų gyventojų socialinè padètis, teisiné situacija ir laisvès lygis buvo aukštesnis nei stabilių regionų [25, 290].

Asmeninių ryšių ir socialinių interakcijų specifika suformuoja trečiajam laikotarpiui būdingą visuomenès tinklaveiką, kurios svarbiausi bendrieji požymiai buvo asmeninių ir grupių ryšių bei socialinių interakcijų „globalejjimas“, bendruomenių uždarumo mažèjimas ir įvairovès augimas. Kaip ir antruoju laikotarpiu, šie procesai buvo kur kas ryškesni aukštesniuose socialiniuose sluoksniuose. Nepaisant minètų permainų, trečiojo laikotarpio visuomenè gebėjo generuoti dideles socialinio kapitalo vertes. Aukštas socialinio kapitalo lygis šioje visuomeneje galètų iš dalies paaiškinti labai vèlyvą rašytinės teisès atsiradimą LDK. Pirmieji rašytinès teisès dokumentai priskiriami tik Jogailai ir Vytautui, o pirmasis kodeksas - Kazimierui Jogailaičiui. Gali būti, kad LDK visuomenėje sukuriamos aukštos socialinio kapitalo vertès sąlygojo didelị visuomenès narių tarpusavio pasitikejjimą ir menką rašytinès teisès poreikį. Nors bendruomenių socialinio kapitalo verčių kūrimas transformavosi pagal hierarchinị modelį, tačiau tai buvo daugiau "papročių“ nei „rašytinè hierarchija, išsaugojusi „minkštas“ ribas bei socialinio sluoksnio pakeitimo galimybę. Dèl didejjančio atvirumo, įvairovès, kiekybiškai gausesnių bendruomenių tarpusavio ir tarpkultūrinių ryšių inovacijų kiekis turèjo augti, o visuomenès evoliucija - greitėti. Ypač stiprų postūmị šiuo požiūriu atliko krikščionybė, kuri buvo priimama du kartus - 1251 ir 1387 metais. Trečiojo laikotarpio pirmojoje pusėje vykę socialinės organizacijos pokyčiai skatino papročių bei tikejjimo kaitą. XII-XIII a. sandūroje fiksuojami hipotetiniai baltų pasaulěžiūros pokyčiai, atspindèti Sovijaus mite ar mokslininkų teiginiuose apie Šventaragio reformą $[2 ; 37 ; 64]$, rodo valdovo kaip vyriausiojo politinio ir dvasinio vadovo pozicijos formavimąsi. Tokio aukščiausio politinio ir dvasinio valdovo apraiškos matyti vèlesnių laikų žinomoje legendoje, kai Gediminas prašo pagonių žynio paaiškinti (tiksliau - patvirtinti) tai, kas jam tarsi jau yra aišku, o Kęstutis yra pajègus „anuliuoti“ Birutès „vienuoliškus“ ižzadus. Akivaizdu, kad socialiai diferencijuojantis ir hierarchizuojantis visuomenei panašūs pokyčiai turèjo vykti ir Dievų panteone - iškilti aukščiausias vienvaldis Dievas, dievų 
valdovas. Šiuo požiūriu Mindaugo krikštą XIII a. galime interpretuoti kaip siekị dar labiau sustiprinti vienvaldžio lyderio (monarcho) pozicijas. O viena iš pirmojo krikšto nesèkmès priežasčių galèjusi būti vidinis valdančiojo elito nepasirengimas priimti monoteistinę ir universalią religiją, nes, nužudę Mindaugą (valdovo nužudymas - pakankamai dažnas reiškinys viduramžių Europoje), nepanaudojo jo pasiekimų (atsimetė nuo krikšto ir nesikarūnavo Treniotos I vardu). Tokiam valdančiojo elito „nesupratingumui“ ịtaką galèjo padaryti santykinai nedidelè „Mindaugo Lietuvos" kultūrinè ir tautinè ịvairovè bei krikščionybès kaip universalių „socialinių klijų“ būsimoje daugiatautẻje imperijoje nesuvokimas (13). Atsimetus nuo krikščionybès, lokali ir decentralizuota pagonybé, siekiant užtikrinti augančios centralizuotos valstybès dvasinius poreikius, turèjo evoliucionuoti monoteizmo ir valstybinès religijos link. Galime spèti, kad ši evoliucija vyko sunkiai. Dèl šios priežasties ankstyvosios valstybès stadija užsitęsė iki XIV a. pabaigos, o siekiant pokyčių vèl ieškota krikšto galimybių. Plečiantis valstybès teritorijai XIV a. pabaigoje kur kas natūraliau iškyla bendros religijos ir papročių, kaip priemonių didinti visuomenès socialinị kapitalą ir geriau administruoti daugiakultūrę valstybę, klausimas. Krikščionybė buvo universaliausi visuomenès „klijai“, puikiai veikiantys LDK erdvèje, kurioje daug nepažįstamụjų (žmonių su kuriais nèra asmeninių ryšių, bet yra reikalingos socialinès interakcijos). Krikščionybė panaikino LDK kultūrinę izoliaciją, atvèrẻ kelią globaliems asmeniniams ryšiams ir inovacijoms, jos dèka susikūrẻ topografiškai vientisos teritorinès struktūros (parapija, vyskupija), nusistovèjo mokesčių administravimo sistema (dešimtinè) bei formalizavosi hierarchinè viduramžių visuomenès struktūra (kariaujantieji, besimeldžiantieji ir dirbantieji). Socialinio kapitalo požiūriu krikščionybès praktikuojama bendra sekmadieninė malda bažnyčioje turèjo iš dalies pakeisti nesamus asmeninius ryšius ir didinti pasitikèjimą nepažįstamais bendruomenès nariais atviresnèse (pavyzdžiui, miestų) bendruomenėse, siekiant užtikrinti tarpusavio pasitikejjimą ir garantuoti sèkmingas socialines interakcijas. Tai, kad 1387 m. krikštas nesulaukè tokio pasipriešinimo kaip XIII a., greičiausiai buvo ilgametès pagoniškos religijos ir visuomenés evoliucijos pasekmè, o XIV a. pabaigos krikštas tik įtvirtino faktiškai nusistovejjusius socialinius santykius ir buvo visuotinai priimtinas tiek valdančiajam elitui, tiek visuomenei.

Socialinès organizacijos požiūriu trečiuoju laikotarpiu LDK išgyveno ilgą intensyvios evoliucijos laikotarpi nuo ankstyvosios valstybės XIII a. iki brandžios viduramžių valstybès XVI a., nuo asmeniniais „tèvo ir sūnaus“ ryšiais grịstos žemévaldos iki teritorijos kaip topografinio vieneto su priklausomais žmonėmis administravimo. Asmeninès priklausomybès virtimas teritorine ypač ryškus dvarų ekonominiuose dokumentuose. Iki Valaku reformos dvarų inventoriaus pagrindinis ekonominis vienetas buvo tarnyba, tai yra asmuo, ir tik po to jo dirbama žemè. Taip išmatuotą Dubingių dvarą randame 1528 m. inventoriuje [47, 178-186]. Lygiai kaip ir 1529 m. LDK kariuomenès surašyme, jame įvardijami tik žmonės nepažymint jų teritorinės priklausomybės. Valakų reforma

(13) Mindaugo krikšto poveikis baltiškai pasaulèžiūrai nèra plačiau nagrinėtas. Tačiau šis daugiau nei 10 metų trukęs krikščioniškasis laikotarpis neabejotinai (bent jau greta didžiųjų LDK centrų) turejjo palikti dvasinių ženklų. Tik hipotetiškai galime teigti apie besikeičiančios visuomenės ir Mindaugo krikšto sąsajas su laidojimo pilkapiuose išnykimu, griautinio laidojimo atsiradimu [74] ar savitomis laidojimo vandenyje formomis [67; 68], kurios esant atitinkamoms aplinkybèms gali būti traktuojamos kaip valdančiojo elito prastuomenei uždrausto kūnų deginimo marginalinės nykimo apraiškos. Lygiai taip pat tik hipotetiškai galime kalbèti apie tai, kad Mindaugo krikštas buvęs per daug ankstyvas, palyginti su LDK visuomenès raida, ir krikštui visuomenè „pribrendusi“ tik XIV a. pabaigoje. 
paskatino teritorinio pobūdžio pokyčius, kai ekonominiu vienetu tampa valakai ir kaimai. Dubingių mikroregione toki aprašymą randame $1554 \mathrm{~m}$. Nemenčinès ir Linkmenų valsčių inventoriuje [19, 29-86]. Bajoro sąsaja su žeme (vietove) atsiranda ir $1567 \mathrm{~m}$. LDK kariuomenès surašyme. Taigi iš esmès Valakų reforma nubrèžia ežias, supila kapčius ir itvirtina topografiškai vientisos žemès valdos sampratą, kartu nustatydama ir žemès valdos prioritetą ją dirbančio (dažniausia depersonalizuoto) baudžiauninko atžvilgiu. Tai turejjo sukelti nemenkus pokyčius socialinio kapitalo požiūriu, nes dalis asmeninių ryšių ir jais grịstų socialinių interakcijų turèjo būti pakeistos teritoriniais ryšiais ir teritorine nuosavybe grịstomis socialinèmis interakcijomis.

Trečiuoju laikotarpiu turèjo nusistovèti ir specifiniai LDK senjoro ir vasalo santykiai, kai senjoro žeme tampa ne tik ta, kuri priklauso jo šeimai (tèvonija) ar dirbama jo valstiečių, bet ir ta, kurią valdo jo vasalai. Tokius pakeitimus bande ịvesti Mindaugas, o natūraliai jie turejo ịvykti Gedimino valdymo metais [11, 282-283]. Pagal ši modelị valdovas turi teisę neklusnų savo vasalą nuvaryti nuo jo žemès (paskelbti baniciją), o tą sklypą prijungti prie savo valdų ar atiduoti kitam, tačiau valdovo tévoninè ir igyta žemė buvo skiriamos. Nors Lietuvos didysis kunigaikštis Vytautas, vykdydamas administracinę reformą, ir stiprino kadaise iškilusią bajoriją - skyrè juos teritorinių vienetų vadovais ir priešpriešino senajai sričių kunigaikščių paveldimai administracijai, galime manyti, kad didieji kunigaikščiai stengèsi patys administruoti senąsias tèvonines (domeno) valdas ir jų neskirdavo beneficijomis naujai kylančiai bajorijai, tačiau nevengè jai dalyti vẻliau igytų teritorijų. Nalšia, Mindaugo laikais prijungta teritorija, buvo tinkama beneficijų dalyboms, todèl Lietuvos didysis kunigaikštis Vytautas bei kiti XV a. LDK valdovai iškylantiems didikams (Sakams, Radviloms, Giedraičiams) skyrè valdas šioje teritorijoje. Šiuo atveju matome ir savotišką LDK visuomenès specifiką, kuri greičiausiai buvo sąlygota ankstyvojoje valstybeje buvusių labai tvirtų nerašytų asmeninių valdovo ir jo aplinkos (patriarchalinès šeimos) ryšių. Asmeninių ryšių tinklas išlaikẻ LDK valdovo kaip nuo kariaunos priklausomo ir savo valdžios paveldejimu neperduodančio karo vado rinkimų rudimentus, neleido LDK valdovams tapti nei rytietiško pavyzdžio despotais, nei vakarietiškais absoliučiais monarchais, o pavertė juos panašesnius ị iki gyvos galvos renkamus „prezidentus“. Gediminaičiams būdingos monarcho valdžios tradicijos buvo suformuotos pagoniškoje Lietuvoje [11, 259-261]. LDK kaip vakarų europietiško tipo viduramžiškos visuomenès tapsmas užtruko iki XV a. pab. - XVI a. vidurio - laikmečio, kai Vakarų ir Vidurio Europa paliko viduramžius ir izženge i renesansą. Tik Valakų reformos metais galutinai ịtvirtinama baudžiava, XVI a. suformuojamas visą buvusią pagonišką Lietuvos dali apimantis katalikišku parapijų tinklas, pasirodo rašytinių įstatymų rinkiniai, įkuriama kolegija ir universitetas, atliekama administracinè-teritorinè reforma, suformavusi topografiškai vientisus LDK administracinius-teritorinius vienetus.

\section{IŠVADOS}

1. Remiantis požiūriu, kad populiacijos dydis yra vienas svarbiausių socialinès sistemos parametrų, straipsnyje modeliuojamo visuomenès raidos proceso atskaitos tašku pasirinktas gyventojų skaičius (populiacijos dydis), o socialinès organizacijos raidos stimuliuojančia jèga pripažistamas gyventojų skaičiaus augimas. Tolygios evoliucijos laikotarpiais gyventojų skaičiaus augimas skatino ūkininkavimo pokyčius ir inovacijų diegimą, Lietuvos atveju tai didino žemdirbystès reikšmę bendroje ūkininkavimo struktūroje, lètino žemès nualinimo procesus ir mažino bendruomenių mobilumą. Tokie ekonominiai pokyčiai lèmé socialines 
permainas ir galiausiai turèjo paskatinti „demografinį šuolị“, kuris stimuliavo modeliuojamo ciklo pasikartojimą kokybiškai aukštesniu lygiu (spirale) iš naujo tolygiai didejjant gyventojų skaičiui. Dubingių mikroregiono socialinès organizacijos raida modeliuojama remiantis ekonomine raida ir išskiriant mažiausiai tris I-XVI a. chronologinius laikotarpius: pirmasis - lydiminès žemdirbystès, antrasis - ariamosios, dirvoninės ir dvilauke sejjomaina pagristos žemdirbystès ir trečiasis - ariamosios, trilauke sèjomaina pagrịstos žemdirbystès.

2. Pirmuoju laikotarpiu (I-II, IV a.) Dubingių mikroregione vyravusi ūkinès veiklos struktūra skatino visus bendruomenès narius veikti kartu, bendruomenès buvo nedidelès, pakankamai mobilios ir išsibarsčiusios dideliuose plotuose, skirtingų bendruomenès narių (grupių) socialinè diferenciacija nebuvusi ryški, o paskiro individo ar nedidelès šeimos išgyvenimo galimybès atskirai nuo bendruomenès buvo menkos. Dèl bendros veiklos ir santykinai nedidelio bendruomenès narių skaičiaus (apie 20-30 asmenų) asmeniniai ryšiai bendruomenès viduje buvo labai stiprūs, o dèl didelių atstumų tarp bendruomenių šie ryšiai už bendruomenès ribų - decentralizuoti ir silpni. Dèl neryškios socialinès diferenciacijos asmeniniai ryšiai buvo vien horizontalūs (nehierarchiniai). Bendruomenès viduje vykusios socialinès interakcijos taip pat buvo horizontalios. Jos turejo būti stipriausios asmeniniu lygmeniu, nes mažoji šeima (kaip asmenų grupė) dar nebuvo tapusi ịtakingu socialiniu vienetu. Socialinès interakcijos tarp skirtingų bendruomenių taip pat turëjo būti horizontalios. Jos buvo silpnos, ritualinio (bendros šventès, vedybų ryšiai ar pan.) ar ekonominio (resursų mainai) pobūdžio. Socialinès interakcijos su geografiškai nutolusiomis bendruomenėmis (kitų kultūrų žmonėmis) buvo atsitiktinès. Remiantis nusistovejusiais teoriniais modeliais, šis laikotarpis gali būti ịvardytas kaip „,segmentuotos visuomenės“ laikotarpis.

3. Antruoju laikotarpiu (II-IV, XI-XIII a.) pasikeitęs ekonominis gyvenimas sudare sąlygas iškilti monogaminei šeimai kaip savarankiškam ekonominiam bei socialiniam vienetui, padidino pardavimui skirtos produkcijos kiekị ir sukūrè prielaidas individualiai privatinei žemès nuosavybei. Tai sudarè sąlygas šeimai (giminei) tapti pamatine visuomenès korporacine gardele, pagrindiniu socialinio kapitalo kūrimo vienetu, su kitomis šeimomis bendraujančiu per giminyste grịstus asmeninius ryšius ir šiais ryšiais grịstas socialines interakcijas. Dèl šių procesų iš esmès horizontali socialinè struktūra turèjo keistis ịgydama netaisyklingo paraboloido formą. Viena vertus, mažosios šeimos tarpusavio ryšiai ir šeimos narių ryšiai su kitais bendruomenès nariais turèjo hierarchizuotis, kita vertus, bendruomenès viduje vykstant socialinès diferenciacijos procesams ir formuojantis vadystei dalis horizontalių asmeninių ryšių bendruomenès viduje šiuo laikotarpiu turèjo vertikalèti. Nepaisant visuomenès socialinės diferenciacijos, aukštesniųjų ir žemesniųjų socialinių sluoksnių bendravimas išlaikẻ daugumą tiesioginių asmeninių ryšių ir tiesioginių, labai individualių interakcijų. Tarp skirtingų bendruomenių ryšiai turejjo stiprèti. Šiuo laikotarpiu per karo žygius, vedybų tinklus, prekybos ryšius turẻjo pradèti formuotis nuolatinių asmeninių ryšių tinklas su nutolusių kitos kultūros bendruomenių nariais. Socialinès interakcijos kito kartu su socialiniais ryšiais. Remiantis nusistovejjusiais teoriniais modeliais, šis laikotarpis gali būti ịvardytas kaip „vadystès“ laikotarpis.

4. Trečiuoju laikotarpiu (XI-XIII, XVI a.) toliau vyko turtinès diferenciacijos ir ja grịstos socialinės diferenciacijos procesai, formavosi LDK viduramžių feodalinė visuomenė. Tačiau, skirtingai nuo feodalizacijos procesų krikščioniškoje Vakarų Europoje, besiformuojančioje LDK valstybès erdvejje nesusidarè aiškiomis, juridiškai apibrěžtomis korporacinėmis grupėmis grịsta socialinè struktūra ir pamatiniu korporaciniu vienetu tapo šeima / giminè. Bendruomenès viduje svarbiausi buvo grupių (šeimų) ir asmeniniai horizontalūs ryšiai. 
Vykstanti socialinè diferenciacija turèjo silpniau pažeisti turtingumu besiskiriančių grupių vertikalius ryšius, ir jie, net formuojantis valstybei, turejjo išlikti stipresni nei luominèje Vakarų Europos visuomenejje ar bizantiniu despotizmu gristoje rytų krikščioniškoje visuomenèje. Skirtingų bendruomenių tarpusavio ir asmeniniai ryšiai su kitų kultūrų bendruomenèmis šiuo laikotarpiu toliau stiprejjo. Socialinès interakcijos bendruomenès viduje išliko panašios kaip ir antruoju laikotarpiu. Trečiuoju laikotarpiu pastebimas socialinių interakcijų tarp skirtingų bendruomenių intensyvejjimas ir valdančiojo elito "globalių“" socialinių interakcijų sustiprẻjimas. Remiantis nusistovejjusiais teoriniais modeliais, šis laikotarpis gali būti įvardytas kaip „ankstyvosios valstybès“ laikotarpis.

Gauta 20130830

Priimta 20131126

\section{Literatūra}

[1] ALEKSANDRAVIČIUS, Egidijus; KULAKAUSKAS, Antanas. Nuo amžių slenksčio. Naujausia Lietuvos XIX amžiaus istoriografija. Darbai ir dienos, 2001, t. 28, p. 7-31.

[2] BERESNEVIČIUS, Gintaras. Baltu religinès reformos. Vilnius: Taura, 1995.

[3] BRZOSTOWICZ, Michał; PRZYBYL, Maciej; SIKORSKI, Dariusz. Archeologia versus historiam - historia versus archeologam. Poznan: Poznańskie Towarzystwo Przyjaciół Nauk, 2012.

[4] BUMBLAUSKAS, Alfredas. Senosios Lietuvos istorija, 1009-1795. Vilnius: R. Paknio 1-kla, 2005.

[5] BUMBLAUSKAS, Alfredas; ŠEPETYS, Nerijus. Sovietine Lietuvos istoriografija: teoriniai ir ideologiniai kontekstai. Vilnius: Vilniaus universiteto l-kla, 1999.

[6] CALHOUN, Craig. Dictionary of the Social Sciences. Oxford: Oxford University Press, 2002.

[7] CARNEIRO, Robert L. The Chiefdom: Precursor of the State. The Transition to Statehood in the New World. New York: Cambridge University Press, 1981.

[8] CASTELLS, Manuel. Tinklaveikos visuomenes raida. Kaunas: Poligrafija ir informatika, 2005.

[9] COLEMAN, James S. Social Capital in the Creation of Human Capital. The American Journal of Sociology, 1988, Vol. 94, p. 95-120.

[10] DUBONIS, Artūras. Mindaugo knyga: istorijos šaltiniai apie Lietuvos karalių. Vilnius: Lietuvos istorijos instituto l-kla, 2005.

[11] DUBONIS, Artūras; BARONAS, Darius; PERTRAUSKAS, Rimvydas. Lietuvos istorija. T. III. XIII a. - 1385 m. Valstybes iškilimas tarp Rytu ir Vakarų. Vilnius: Baltos lankos, 2011.

[12] DURKHEIM, Emile. De la division du travail social. Paris, 1893.

[13] Lietuvos istorija. T. I. Akmens amžius ir ankstyvasis metalu laikotarpis. Ats. red. A. Girininkas. Vilnius: Baltos lankos, 2005.

[14] GRIGALAVIČIENĖ, Elena. Žalvario ir ankstyvasis geležies amžius Lietuvoje. Vilnius: Mokslas, 1995.

[15] GUDAVIČIUS, Edvardas. Lietuvos istorija. Nuo seniausių laiku iki 1569 metų. Vilnius: Mokslas, 1991.

[16] GUREVIČIUS, Aronas. Viduramžių kultūros kategorijos. Vilnius: Mintis, 1989.

[17] HANIFAN, Judson L. The Rural School Community Center. Annals of the American Academy of Political and Social Science, 1916, Vol. 67, p. 130-138.

[18] JANKAUSKAS, Rimantas. Kai kurie Lietuvos praeities populiacijų biosocialinės diferenciacijos rodikliai. Lietuvos archeologija. Vilnius: Lietuvos istorijos institutas, 1998, t. 15, p. 447-471.

[19] JABLONSKIS, Konstantinas. Istorijos archyvas. XVI amžiaus Lietuvos inventoriai. Kaunas: Vytauto Didžiojo universitetas, 1934.

[20] JØRGENSEN, Lars. Bakkegård and Glasergård. Two Cemeteries from the Late Iron Age on Bornholm. Copenhagen: Akademisk Forlag, 1990. 
[21] JOVAIŠA, Eugenijus. Baltụ visuomenė ankstyvųjų viduramžių pradžioje (V-VI a.). Istorija. Mokslo darbai, 2006, t. 64, p. 7-68.

[22] JOVAIŠA, Eugenijus. Aisčiai. Kilmé. Vilnius: Edukologija, 2012.

[23] JURGINIS, Juozas. Lietuvos valstiečiu istorija nuo seniausių laiku iki baudžiavos panaikinimo. Vilnius: Mokslas, 1978.

[24] KIAUPA, Zigmantas; KIAUPIENĖ, Jūratė; KUNCEVIČIUS, Albinas. Lietuvos istorija iki 1795 metu. Vilnius: Mokslas, 1995.

[25] KIAUPIENE, Jūraté; PETRAUSKAS, Rimvydas. Lietuvos istorija. T. IV. Nauji horizontai: dinastija, visuomene, valstybè. Vilnius: Baltos lankos, 2009.

[26] KULIKAUSKAS, Pranas; KULIKAUSKIENĖ, Regina; TAUTAVIČIUS, Adolfas. Lietuvos archeologijos bruožai. Vilnius: Mokslas, 1961.

[27] KUNCEVIČIUS, Albinas; LAUŽIKAS, Rimvydas; RUTKAUSKAITĖ, Indrè; ŠMIGELSKAS, Ramūnas. Radvilu rūmai Dubingiuose. Vilnius: Vilniaus universiteto l-kla, 2011.

[28] KUNCEVIČIUS, Albinas; LAUŽIKAS, Rimvydas; AUGUSTINAVIČIUS, Renaldas; ŠMIGELSKAS, Ramūnas. Dubingių istorinè žemè - Rytų Lietuvos pilkapių kultūros ar lietuvių pilkapių teritorija? Lituanistica, 2012, t. 58, Nr. 1, p. 12-35.

[29] KUNCEVIČIUUS, Albinas; LAUŽIKAS, Rimvydas; AUGUSTINAVIČIUS, Renaldas; ŠMIGELSKAS, Ramūnas. Rytų Lietuvos teritorinis modelis I-XV a. Lietuvos archeologija [itteikta spaudai].

[30] KURILA, Laurynas, Vytis. Socialinių santykių atspindžiai Rytų Lietuvos pilkapių degintinių kapų medžiagoje. Archaeologia Lituana, 2002, t. 3.

[31] KURILA, Laurynas, Vytis. Vaiko statusas Rytų Lietuvoje geležies amžiuje. Archaeologia Lituana, 2007, t. 8 .

[32] KURILA, Laurynas, Vytis. Socialinè organizacija Rytu Lietuvoje III-XII a. (laidojimo paminklu duomenimis). Daktaro disertacija (humanitariniai mokslai, istorija $(05 \mathrm{H})$. Vilnius: Vilniaus universitetas, 2009.

[33] KURILA, Laurynas, Vytis. Socialinis statusas ir lytis: geležies amžiaus Rytų Lietuvos socialinès organizacijos analizė. Lietuvos archeologija, 2009, t. 35.

[34] LASINSKAS, Povilas. Istorijos mokslas Vytauto Didžiojo universitete 1922-1940 metais. Vilnius: Vaga, 2004.

[35] LAUŽIKAS, Rimvydas. Dubingių mikroregiono ekonominės raidos specifika I a. - XVI a. viduryje. Lietuvos istorijos studijos [itteikta spaudai].

[36] LEE, Daniel B. Ritual and the Social Meaning and Meaninglessness of Religion. Soziale Welt 2005 , t. 5 , p. $7-18$.

[37] LEMEŠKIN, Ilja. Sovijaus sakme ir 1262 metu chronografas (pagal Archyvinį, Varšuvos, Vilniaus ir I. J. Zabelino nuorašus). Vilnius: Lietuvių literatūros ir tautosakos institutas, 2009.

[38] LOWMIANSKI, Henryk. Zaludnienie państwa litewskiego $w$ wieku XVI: zaludnienie w roku 1528. Poznań: Wydawnictwo Poznańskie, 1998.

[39] MICHELBERTAS, Mykolas. Senasis geležies amžius Lietuvoje. I-IV amžius. Vilnius: Mokslas, 1986.

[40] National Monuments Record Thesauri. [interaktyvus]. London: English Heritage, 1999-2013. Prieiga per internetą: $<\mathrm{http}: / /$ thesaurus.english-heritage.org.uk $>$.

[41] Network. Oxford Dictionary. [interaktyvus]. Oxford: Oxford University Press, 2013. Prieiga per internetą: internetu: $<$ http://oxforddictionaries.com/definition/english/network? q=network $>$.

[42] NUMMELA, Ilkka. Regional Inequality. Physical and Cultural Space in Pre-industrial Europe. Methodological Approaches to Spatiality. Lund: Nordic Academic Press, 2011, p. 335-375. 
[43] OGILVIE, Sheilagh. Social Capital, Social Networks, and History. [interaktyvus]. Cambridge: Faculty of Economics, University of Cambridge, 2000. Prieiga per internetą: <http://www.econ.cam. ac.uk/faculty/ogilvie/social-capital-and-history.pdf>.

[44] OGILVIE, Sheilagh. The Use and Abuse of Trust: Social Capital and its Deployment by Early Modern Guilds. CESifo Working Papers, No. 1302. [interaktyvus]. Munich: Leibniz Institute for Economic Research at the University of Munich, 2004. Prieiga per internetą: <http://www.econstor. eu/bitstream/10419/18667/1/cesifo1_wp1302.pdf>.

[45] OBERG, Kalervo. Types of Social Structure among the Lowland Tribes of South and Central America. American Anthropologist, 1955, Vol. 57, issue 3, p. 472-482.

[46] PARSSINEN, Martti; SHAAN, Denise; RANZI, Alceu. Pre-Columbian Geometric Earthworks in the Upper Pur'us: A Complex Society in Western Amazonia. Antiquity, 2009, Vol. 83, p. 10841095 .

[47] PIETKIEWICZ, Krzysztof. Najstarszy inwentarz dobr radziwiłłowskich z 1528 r. LituanoSlavica Posnaniensia, 1985, t. 1, s. 175-186.

[48] PRIGOGINE, Ilya. Tikrumo pabaiga: laikas, chaosas ir nauji gamtos desniai. Vilnius: Margi raštai, 2006.

[49] PUTNAM, Robert D. Democracies in Flux: The Evolution of Social Capital in Contemporary Society. Oxford: Oxford University Press, 2002.

[50] RABIKAUSKAS, Paulius. Vilniaus akademija ir Lietuvos jèzuitai. Vilnius: Aidai, 2002.

[51] RAGAUSKIENE, Raimonda; KARVELIS, Deimantas. Iš Radvilu giminès istorijos: Dubingiu kunigaikštystè 1547-1808 m. Vilnius: Vilniaus pedagoginio universiteto l-kla, 2009.

[52] RENFREW, Colin; BAHN, Paul. Archaeology: Theories, Methods and Practice. London: Thames and Hudson, 1991.

[53] RIMANTIENĖ, Rimutè. Akmens amžius Lietuvoje. Vilnius: Mokslas, 1984.

[54] RINGSTED, Nils. Household Economy and Archaeology: Some Aspects of Theory and Applications. Stockholm: University of Stockholm, 1992.

[55] ROGERS, Everett M. Diffusion of Innovations. New York: Free Press, 2003.

[56] RUMMEL, Rudolf J. Understanding Conflict and War. The Conflict Helix. Beverly Hills, California: Sage Publications, 1976.

[57] Sakmė [Ant Šatrijos kalno Joniniu nakti raganos renkasi]. BsTB 12 203-13. [interaktyvus]. Vilnius: Lituanistikos paveldo informacinè sistema Aruodai, 2003-2013. Prieiga per internetą: $<$ http://www.aruodai.lt/paieska/objektas.php?OId=4630 $>$.

[58] SHEINKMAN, Jose A. Social Interactions. Palgrave Dictionary of Economics. [interaktyvus]. Basingstoke: Palgrave Macmillan, 2008. Prieiga per internetą: <http://www.princeton.edu/ joses/ wp/socialinteractions.pdf $>$.

[59] SKYTTNER, Lars. General Systems Theory. Problems, Perspectives, Practice. London: World Scientific Pub Co Inc, 2005.

[60] Social Capital Assessment Tool. [interaktyvus]. Washington: The Word Bank Group, 2013. Prieiga per internetą: <http://web.worldbank.org/WBSITE/EXTERNAL/TOPICS/ EXTSOCIALDEVELOPMENT/EXTTSOCIALCAPITAL/0,,contentMDK:20193049 menuPK:418 220 pagePK:148956 piPK:216618 theSitePK:401015,00.html>.

[61] Social Organization. Merriam-Webster Dictionary. [interaktyvus]. Springfield: MerriamWebster, Incorporated, 2013. Prieiga per internetą: <http://www.merriam-webster.com/dictionary/ social\%20organization>

[62] ŠMIGELSKAS, Ramūnas. Jutoniu pilkapyno 2012 metu archeologiniu tyrimu ataskaita. Vilnius: Kultūros paveldo akademija, 2013. [rankraštis] 
[63] TAUTAVIČIUS, Adolfas. Vidurinysis geležies amžius Lietuvoje (V-IX a.). Vilnius: Pilių tyrimo centras „Lietuvos pilys“, 1996.

[64] VAITKEVIČIENĖ, Daiva; VAITKEVIČIUS, Vykintas. XIII a. Lietuvos valstybinès religijos bruožai. Lietuvos archeologija, 2001, t. 21, p. 311-334.

[65] VAITKEVIČIUS, Bronius. Lietuvos TSR istorija. Nuo seniausiu laiku iki 1917 metų. Vilnius: Mokslas, 1986.

[66] VAITKEVIČIUS, Vykintas. Senosios Lietuvos šventvietés. Aukštaitija. Vilnius: Diemedis, 2006.

[67] VAITKEVIČIUS, Vykintas. Santakos pilkapiai (Vilniaus r.). Lietuvos archeologija, 2007, t. 30, p. 181-212.

[68] VAITKEVIČIUS, Vykintas. Bajorų kapinynas. Archeologiniai tyrinèjimai Lietuvoje 2008 metais. Vilnius: Kultūros paveldo departamentas, 2009, p. 134-140.

[69] VANGELISTI, Anita L.; PERLMAN, Daniel. The Cambridge Handbook of Personal Relationships. Cambridge: Cambridge University Press, 2006.

[70] VĖLIUS, Norbertas. Baltų religijos ir mitologijos šaltiniai. Nuo seniausių laikų iki XV amžiaus pabaigos. T. 1. Vilnius: Mokslo ir enciklopedijų 1-kla, 1996.

[71] Visuomenè. Lietuvių kalbos žodynas. [interaktyvus]. Vilnius: Lietuvių kalbos institutas, 2008. Prieiga per internetą: <http://www.lkz.lt/startas.htm>.

[72] VOBOLEVIČIUS, Vincentas. Statistinè duomenų analizè. [interaktyvus]. Kaunas: KTU Politikos ir viešojo administravimo institutas, 2013. Prieiga per internetą: $<$ http://www.lidata.eu/index. php?file=files/mokymai/sda/sda.html\&course_file=sda_I_1.3.html $>$.

[73] WARRICK, Gary. A Population History of the Huron-Petun, A. D. 500-1650. Cambridge: Cambridge University Press, 2008.

[74] ЙОНАЙТИС, Ритис. Новейшие раскопки на территории „CIVITAS RUTENICA“ в Вильнюсе: предворительный анализ результатов. Археология и история Пскова и Псковской земли. Псков, 2008.

[75] КРАСНОВ, Юрий Алексеевич. Раннее земледелие и животноводство в тесной полосе восточной Европы: 11 тысячелетие до н. э. - первая половина 1 тысячелетия н.э. Москва: Наука, 1971.

[76] Материалы для географии и статистики России, собранные офицерами Генерального штаба. Санкт-Петербург, 1861.

[77] МЕДВЕДЕВ, Александр Михайлович. Верхнее понеманье в железном веке и раннем средневековье. Минск: Беларуская навука, 2011.

[78] ОКШОТТ, Эварт. Оружие и воинские доспехи Европы. С древних времен до кониа Средневековья. Москва: Центрполиграф, 2009.

[79] ПАШУТО, Влади́мир Тере́нтьевич. Образование Литовского государства. Москва: Издательство АН СССР, 1959.

[80] СЕДОВ, Валенти́н Васи́льевич. Древнерусская народность. Москва: Языки русской культуры, 1999.

[81] СМИРНОВА, Ольга Всеволодовна; ТУРУБАНОВА, Светлана Афанасьевна. Формирование и развитие восточноевропейских широколиственных лесов в голоцене. Вопросы экотогии и охраны природы. [interaktyvus]. Самара: Самарский университет, 2003. Prieiga per internetą: <http://paleobase.narod.ru/samara.html>. 
RIMVYDAS LAUŽIKAS

\title{
Development of social organization in Dubingiai microregion in the 1 st - the middle of the 16th century: A theoretical model
}

\author{
Summary
}

The article presents the results of social organization change. Based on I. Prigogine's systems theory and theories of social capital, a general theoretical model of the social organization process in the society of the Grand Duchy of Lithuania and a model of social development in the community of a specific microregion of Dubingiai during the period from the beginning of local iron ore extraction (Early Iron Age) to the Wallach reform in the middle of the 16th century is substantiated.

Based on the point of view that the population size is one of the most important social system parameters, the number of residents (population size) was chosen as the benchmark of the social development process modelled in the article, and the increase of population was acknowledged to be a stimulating force of the process of social organization development. During the periods of sustainable evolution, the increase of population induced the changes in farming and introduction of innovations what, in case of Lithuania, increased the significance of arable farming in the general structure of farming, slackened the processes of land degradation and reduced the mobility of communities. Such economic changes induced social changes what, as a final result, had to cause 'demographic jump', which stimulated the recurrence of the modelled cycle in a qualitatively higher level (spiral) as the population was evenly increasing again. The social organization development of the Dubingiai microregion is modelled on the grounds of economic development by singling out at least three chronological periods in the 1st-16th centuries: the first - slash-and-burn agriculture, the second - arable, fallow agricultures and agriculture based on two-field crop rotation, and the third - arable agriculture and agriculture based on three-field crop rotation.

The structure of farming activity that prevailed in the Dubingiai microregion during the first period (1st-2nd/4th centuries) encouraged all the community members to act together, communities were small, quite mobile and scattered over expansive areas, social differentiation of different community members (group) was not strong, and the opportunities for survival of a single individual or small family separately from the community were poor. Due to common activities and a relatively small number of community members (around 20-30 persons), personal relationships inside the community had to be very strong, and due to long distances between the communities, personal relationships outside the communities had to be decentralized and weak. Due to poor social differentiation, personal relationships were all horizontal (not hierarchic). Social interactions inside the communities were horizontal too. They had to be the strongest in the personal level because the small family (as a group of persons) was not an influential social unit yet. Social interactions between different communities had also to be horizontal. They were weak, of ritual (common festivals, marital relationships, etc.) or economical (exchange of resources) nature. Social interactions with geographically remote communities (people from other cultures) were of accidental nature. Adhering to the settled theoretical models this period may be named as a period of "segmented society". 
The economic life that changed during the second period (2nd-4th/11th-13th centuries) established conditions under which a monogamic family as an independent economic and social unit emerged, the quantity of production for sale increased and the presumptions for individual private land ownership appeared. This allowed the family (extended family) becoming a fundamental corporate lattice of the society, the basic unit of social capital creation that communicates with other families via familybased personal relationships and social interactions based on these relationships. Due to these processes, basically horizontal social structure had to change, graphically acquiring the shape of an irregular paraboloid. On the one hand, the interrelationship of a small family and the relationship of family members with other community members had to become hierarchic. On the other hand, a part of horizontal personal relationships inside the community had to become vertical during this period because the processes of social differentiation were going on and the chiefdom was forming inside the communities. Despite social differentiation of the society, communication of higher and lower social strata had maintained most of direct personal relationships and direct, even very individual, interactions. Relationships between different communities had to become stronger. During this period, in military campaigns, wedding networks, trade relations the formation of constant personal relationships with the members of remote communities (of other culture) had to start. Social interactions were varying together with social relations. Adhering to the settled theoretical models this period may be named as a period of "chiefdom".

During the third period (11th-13th/16th centuries), the processes of proprietary differentiation and, on the grounds of it, social differentiation were further going on, the medieval feudal society of the Grand Duchy of Lithuania was forming. But unlike the feudalization processes in Christian Western Europe, the social structure grounded on explicit, legally defined corporate groups did not emerge in the space of the state of the Grand Duchy of Lithuania under formation and the family / extended family became a fundamental corporate unit. Inside the community, relationships of groups (families) and personal horizontal relationships had to be the most important. The ongoing social differentiation had to less disturb vertical relationships of groups of different richness and they, even in the state under formation, had to remain stronger than they were in the estates society of the Western Europe or in the Eastern Christian society grounded on Byzantine despotism. Interrelationships of different communities and personal relationships with the communities of other cultures had to continue developing during this period. Social interactions inside the community had to remain similar to those that existed during the second period. In the third period, the intensification of social interactions between different communities and strengthening of "global" social interactions of the ruling elite are mostly observable. Adhering to the settled theoretical models this period may be named as a period of "the early state".

The formation of the Grand Duchy of Lithuania as a medieval society of the Western European type lasted until the end of the 15th - middle of the 16th century - time when Western and Central Europe left the Middle Ages and entered the Renaissance. Only during the years of Wallach reform the serfdom was finally established, in the 16th century the network of catholic parishes encompassing the whole former pagan part of Lithuania was formed, written codes of laws appeared, college and university were established, administrative-territorial reform that formed topographically solid administrative-territorial units of the Grand Duchy of Lithuania was performed.

Key words: Dubingiai microregion, the Grand Duchy of Lithuania, social organization, social capital, social interactions, social development, the model of process 